
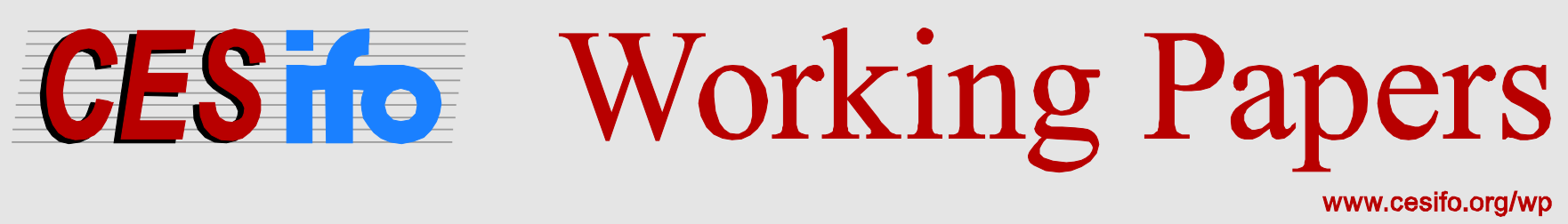

\title{
Did Chinese Outward Activity Attenuate or Aggravate the Great Recession in Developing Countries?
}

\author{
Bastian Gawellek \\ Jingjing Lyu \\ Bernd Süssmuth
}

\begin{abstract}
CESIFO WORKING PAPER NO. 5735
CATEgory 6: FisCAl POLICY, MaCROECONOMICS AND GROWTH

JANUARY 2016
\end{abstract}

An electronic version of the paper may be downloaded

- from the SSRN website:

- from the RePEc website:

- from the CESifo website:

wWw.SSRN.com

Www.RePEc.org

www.CESifo-group.org/wp 


\title{
Did Chinese Outward Activity Attenuate or Aggravate the Great Recession in Developing Countries?
}

\begin{abstract}
Using data on Chinese large-scale overseas investment and project contracts by sector, we analyze whether Chinese outward activity (COA) before the crisis worsened or alleviated the contractionary phases in developing countries. We find that, on average, COA did not increase vulnerability to the global recession. However, both the sectoral targeting and the size of the pre-crisis engagement matter: While COA in clearly to financial markets tied sectors implied an aggravation, substantial precrisis investment in the energy, metals and transportation industries implied an attenuation of the slump.
\end{abstract}

JEL-codes: F200, F300, F400, F630.

Keywords: global crisis, offshoring, developing countries, sectoral transmission.

Bastian Gawellek

Institute for Empirical Research in Economics / University of Leipzig

Grimmaische Str. 12

Germany - 04109 Leipzig gawellek@wifa.uni-leipzig.de
Jingjing Lyu

Institute for Empirical Research in

Economics / University of Leipzig

Grimmaische Str. 12

Germany - 04109 Leipzig

lyu@wifa.uni-leipzig.de

Bernd Süssmuth

Institute for Empirical Research in

Economics / University of Leipzig

Grimmaische Str. 12

Germany - 04109 Leipzig

suessmuth@wifa.uni-leipzig.de

We would like to thank Kwan E. Choi, Eden Yu, Rolf Langhammer, Matthias Busse, Sebastian Krautheim, and participants of the Rimini Centre for Economic Analysis Growth and Development Workshop, the German Economic Association Research Committee on Development Economics Annual Meeting at Kiel, the European Economics and Finance Society Conference at Brussels, the German Economic Association Annual Meeting at Münster, and the Leipzig Lunch-time Economics Seminar for many helpful comments and discussions. The ususal disclaimer applies. 


\section{Introduction}

In theory, financial globalization and capital inflows into developing countries in the form of foreign direct investment (FDI) and project cooperations in areas such as engineering and construction bear - at least in the short run and in the absence of crowding out domestic activity- gains in efficiency and productivity (Brems 1970; Rodríguez-Clare 1996; De Mello 1997; Borensztein et al. 1998; Markusen and Venables 1999; Javorcik 2004; Campos and Kinoshita 2007; Lin and Saggi 2007). However, neither the financial market nor the productivity related empirical literature produce clear-cut evidence supporting this view (Prasad et al. 2003; Alfaro et al. 2004; Blonigen and Wang 2004; Görg and Greenaway 2004; Stulz 2005; Henry 2007; Beugelsdijk et al. 2008; Herzer et al. 2008; Rodrik and Subramanian 2009; Buchanan et al. 2012). Similarly, studies that consider different modes of entry -in particular, mergers and acquisitions (M\&A) vs. greenfield FDI- do not come to a unanimous conclusion regarding positive externalities (Mencinger 2003; Herzer 2012; Yokota and Chen 2012; Ashraf and Herzer 2014; Kabiraj and Sinha 2015).

A growing literature studies determinants of Chinese outward activity (COA) in developing, non-OECD or low and lower-middle income countries (Buckley et al. 2007; Cheung and Qian 2009; Huang and Wang 2011, 2013; Cheung et al. 2012; Kang and Jiang 2012; Kolstad and Wiig 2012; Ramasamy et al. 2012; Amighini et al. 2013; Guo et al. 2014). Analyzing the phenomenon from different perspectives, the vast majority of studies finds either trade facilitation or natural resources or both as significant determinants of COA. In few cases also a significant (and mostly negative) impact from the quality of institutions in the host country is confirmed. Overall, economic fundamentals, such as GDP growth rates, and a clear-cut short-run market-seeking motive seem not to play a significant role in the choice of a COA-host country. Some authors claim this to be due to COA being usually not aimed at expanding production overseas but foremost at strengthening industries at home (Huang and Wang 2011, 2013).

The impact of the 2008 starting to spread global economic crisis on developing countries

or, in general, on emerging markets, which represent potential FDI hosts, so far has been 
given relatively little attention in the literature. A notable exception is the seminal study by Tong and Wei (2010). It analyzes firm-level data in the manufacturing sectors for 24 emerging markets finding that the susceptibility to the global economic crisis crucially depends on the composition of capital inflows in terms of their liquidity. The results suggest that FDI activity generally alleviates susceptibility, while more liquid investments from outwards before the crisis increase it.

Against this backdrop, our research objective can be summarized in the following thought experiment and research questions. Given that COA really can be found to be widely independent of short-run market motives, the central open questions to be addressed are:

1. If we classify sector-by-sector developing countries based on their ex ante, i.e. precrisis, exposure to COA, will this classification help us to forecast the ex post, i.e. during and post-crisis, cyclical growth performance of these developing countries?

2. Does the mode of entry of COA in developing countries matter on that score?

Our study contributes to the literature in several regards. First, it contributes to the offshoring literature by analyzing COA determinants taking into account the sectoral nature of Chinese large-scale FDI and contracted projects in developing countries. Following Cheung et al. (2012) we test for a sequential nature of the decision, separating the dichotomous investment decision from the invested amounts, by relying on a two-stage Heckman selection model. Confirming the independence of the selection into pre-crisis COA-treatment from short-run market-seeking motives, we proceed with an identification strategy that allows a quantitative assessment of whether pre-crisis COA worsened or alleviated the contractionary phases in developing countries. Thus, we also contribute to the recent strand of literature studying the effects of pre-crisis capital inflows on economic performance at business cycle frequencies in host countries (Blanchard et al. 2010, Tong and Wei 2010, Claessens et al. 2012). To add to the literature, we thoroughly study differential effects in six different broadly defined sectors going beyond an exclusive manufacturing industries examination. According to the central finding by Tong and Wei (2010), shocks in the course of the Great Recession have been less severe for manufacturing firms in 
emerging economies that have had a higher pre-crisis exposure to FDI. Our findings confirm the decreased crisis vulnerability, however, only for voluminous pre-crisis FDI in the energy, metals and transportation industries. In contrast, pre-crisis FDI in finance and real estate sectors, coined by singular high-volume investments, implies an aggravation of the recessionary phase. Additionally, we extend a recently available dataset, which is in several regards superior to official data, to study whether the mode of entry of pre-crisis COA matters for the industry-specific vulnerability to or cushioning of global recessionary effects on hosts. Our data allow us to discriminate three distinct modes: large-scale contracted services, for which ownership of the host country is maintained, and M\&A- as well as greenfield-FDI projects. Finally, we conduct some robustness analysis assessing the idiosyncratic nature of Chinese outward FDI effects on developing countries compared to the ones from the rest of the world.

The remainder of the paper is organized as follows. Section 2 describes our data and analyzes the determinants of the selection of developing countries into "COA-treatment" prior to the spread of the crisis. In Section 3 we identify the differential crisis effect and interpret our findings. Section 4 concludes.

\section{Pre-crisis COA and its determinants}

\subsection{Data}

Our data of COA is drawn from the Heritage Foundation China Global Investment Tracker (CGIT) database. It comprises information on investments with a volume of US \$100 million or more as well as on contracted engineering and construction services by Chinese firms overseas from three years before the global spread of the crisis, i.e. from 2005, to 2014. We define overall COA as the sum of FDI and these contracts. The sectoral breakdown of the dataset roughly coincides with SIC alphanumeric industry divisions. It identifies the following nine sectors: energy and power, metals, finance, real estate and construction, transport, agriculture, technology, chemicals, and others (Scissors 2013). 
Using the World Bank's definition of developing countries, 105 countries in the relevant period from 2005 to 2014 qualify as developing. The Heritage Foundation CGIT database identifies about half of them, i.e. 50 economies, as COA host countries. A comprehensive list of these countries is given in Table A.1 in the Appendix. As can be seen from the two global maps in Figure 1 that have been slightly cropped due to our focus on developing countries, Chinese large-scale investment activity (left schedule) is clearly less dispersed across developing countries than is its offshoring activity in the form of contracted engineering and construction services (right schedule). The decisive legal difference between the two shown forms of offshoring lies in ownership of the host country being maintained in the case of contracts (Scissors 2013, 2015). Due to highlighting the role of Nigeria, Libya, and Iran as prime targets of Chinese offshore investment activity, the left map in Figure 1 seems to underline the two widely held beliefs that COA is dominated by a quest for natural resources and that Chinese firms do not shy away from investing in "rogue nations" at a large scale; see, for instance, the discussion in Dreher and Fuchs (2015). This impression is to some extent qualified if another part of China's global footprint, which is made of contracted engineering and construction services as displayed in the right map of Figure 1, is considered. For these projects, which usually represent multi-year contracts involving the importation of Chinese (white collar) workers (Scissors 2015), the strikingly targeted countries are more dispersed. They range from Venezuela in Latin America, Algeria and Nigeria on the African continent, to the Southeast Asian economies of Vietnam and Indonesia. Including contracts of exported services as central part of COA is crucial as it represents a recent insight from firm-level data that positive externalities due to FDI in developing countries mostly do not materialize, even in the absence of infrastructural hurdles, due to lack of skilled workers (Kinda 2010). The importation of the latter from China to the contract partners, potentially for a couple of years, is a defining characteristic of Chinese offshore-contracts.

Although the CGIT data is roughly in accordance with the official Chinese Ministry of Commerce (CMOC) figures, at least at annual frequency and for the period 2005-2010, it is clearly preferable for the following two main reasons. First, while the CMOC treats 
Figure 1: China's offshoring (FDI and contracts) in developing countries, 2005-2014
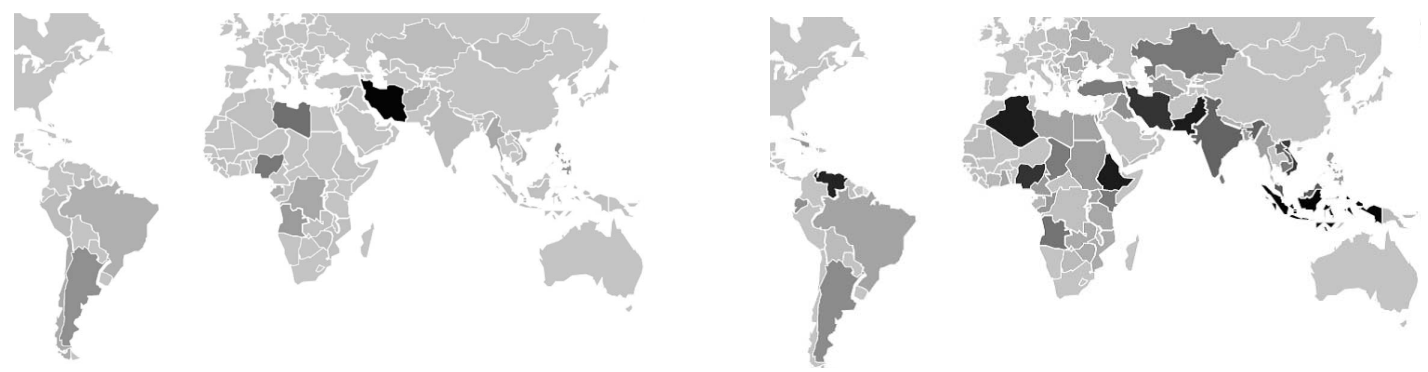

Note: left map — FDI, right map — contracts; shading — total volume (in US \$);

Source: Heritage Foundation CGIT database

Hong Kong separately as final destination for outward investment (usually receiving a minimum of 40 to 60 percent of the official total investment volume), the CGIT database treats Hong Kong as part of China. In the latter case, Hong Kong is seen as transit point: Funds remaining in Hong Kong are not tracked, while passed through money that is temporarily parked in Hong Kong is recorded. This feature of CGIT data represents a clear advantage over official data and studies relying on them in terms of overcoming an evident allocation bias. ${ }^{1}$ Additionally, as opposed to the standard industry structure of CGIT data, the sectoral breakdown of official, i.e. in particular, of CMOC data, is not very meaningful as it contains non-standard classifications such as "business and leasing services" (Scissors 2015).

Table 1 gives besides the regional also a sectoral breakdown of COA in developing countries for the pre-crisis period. We define the pre-crisis period to begin with the year 2005. This seems justified as 2005 actually marks the start of the era of large-scale COA. Although out of the sphere of developing countries, it is widely agreed on that the Lenovo acquisition of the IBM personal computer unit in 2005 launched a new era of Chinese large-scale outward investment. Global COA quintupled in 2005 over the preceding fiscal

\footnotetext{
${ }^{1}$ The interested reader is referred to Rosen and Hanemann (2009, Figure 2, p. 5) to see how obvious this bias actually is and how it thwarts a meaningful representation and interpretation of the geographical distribution of Chinese outbound FDI activity.
} 
Table 1: Sectoral and regional breakdown of developing countries COA, 2005-2008 (\%)

\begin{tabular}{lrrrrrrr}
\hline & Agriculture & Energy & Finance & Metals & Real Estate & Transport & Total \\
\hline Sub-Saharan Africa & 0.13 & 10.40 & 4.52 & 0.55 & 1.11 & 7.44 & 24.15 \\
South America & 0.11 & 2.88 & & 5.23 & 0.76 & & 8.98 \\
North America & & & & 1.06 & & 0.24 & 1.30 \\
Arab World & 0.29 & 1.94 & & 0.76 & 0.43 & 5.80 & 9.22 \\
West Asia & & 32.19 & & 2.67 & 1.57 & 1.70 & 38.13 \\
East Asia & 3.89 & 7.95 & & 3.30 & & 1.65 & 16.79 \\
Europe & & & & & 0.67 & & 0.67 \\
Total & 4.42 & 55.36 & 4.52 & 13.57 & 4.54 & 16.83 & \\
\hline
\end{tabular}

year (Scissors 2015). In the last quarter of 2004, taking effect with fiscal year 2005, the regulatory process of Chinese outbound FDI (OFDI) was rigorously reformed. Exchange controls were further eased and localized. According to Rosen and Hanemann (2009) these measures were the last part of the fifth phase of the Chinese OFDI policy framework marking the implementation stage of the "going global" policy. It included central officials and local governments beginning to provide broad and active assistance for firms with overseas expansion plans. See also the comprehensive list of key OFDI regulations in China provided by Luo et al. (2010). It stresses the fact that the State Development and Reform Commission (SDRC) measure to reform verification and approval procedures for OFDI, permitting grants to all types of companies to invest abroad, at the end of 2004 replaced a policy enacted by the National Planning Commission (NPC) that existed since 1991 (Luo et al. 2010, p. 74).

More than half of the total volume of COA occurs in Asia with the lion's share given for the westernmost subregion of Asia (the Middle East and the Near East) followed by Sub-Saharan Africa, the Arab World, and South America. As regards sectors, energy, transportation, and metals followed by finance and real estate draw the largest volumes in COA again fostering the popular belief of COA being dominated by a hunger for natural resources (Dreher and Fuchs 2015). For comparison, overall COA including developed 
countries in the 2005-2014 period was targeted about one half toward energy sectors, followed by metal (16.1 percent) and transport (11.5 percent), real estate (10.2 percent) and financial industries (5.5 percent). It is worth noting that the substantial finance and real estate sectors' shares (each amounting to about 5 percent) of COA in emerging markets prior to the crisis (Table 1) are due to two striking FDIs: the 20 percent stake of Standard Bank ${ }^{2}$ purchase by the Industrial and Commercial Bank of China (ICBC) in 2007 with a volume of US $\$ 5.6$ billion and the 2006 property purchases by a group of Shanghai based state-owned enterprises in the Russian Federation amounting to US $\$ 1.3$ billion.

\subsection{Selection into pre-crisis COA-treatment}

In the following, we estimate a Heckman selection model for COA-target choice and amounts invested prior to the crisis using a standard set of covariates for two reasons. First, we are aware of the fact that by the nature of the Heritage Foundation data our COA variables are implicitly, as regards COA exposure, and explicitly, with regard to amounts invested, censored from below to exceed US $\$ 100$ million. Whether this circumstance represents a critical data limitation and whether the sequential nature of the decision process - consisting of the two stages COA (binary) choice and amounts to be spent - actually needs to be accounted for can be tested in a Heckman selection model. Secondly, only if we find the selection into the pre-crisis COA-treatment group to be independent of our dependent variable in the analysis of Section 3, i.e. economic performance measured by annual real GDP growth rates, we can start from the premise that the assignment into our treatment group is independent from short-run economic motives. To some extent this ensures an a priori quasi-randomized assignment.

Using a country cross section of average data for the 2005-2008 period (for a list of the seven countries excluded due to data limitations see the first column in combination

\footnotetext{
${ }^{2}$ At the time (until the present day), Standard Bank was (is) South Africa's largest bank by assets and earnings.
} 
with the last column of Table A.1), we estimate the following two-stage model

$$
\begin{gathered}
D_{i}=\beta_{0}+M K T_{i}^{\prime} \beta_{1}+M C R_{i}^{\prime} \beta_{2}+W G I_{i}^{\prime} \beta_{3}+N T R_{i}^{\prime} \beta_{4}+\mu_{i} \\
C O A_{i}=\beta_{0}+M K T_{i}^{\prime} \beta_{1}+M C R_{i}^{\prime} \beta_{2}+W G I_{i}^{\prime} \beta_{3}+N T R_{i}^{\prime} \beta_{4}+\rho \cdot \text { Mills }_{i}+v_{i}
\end{gathered}
$$

where $C O A_{i}$ represents COA amounts in country $i$ rescaled by host population, and

$$
D_{i}= \begin{cases}1 & \text { if } C O A_{i}>0 \\ 0 & \text { otherwise }\end{cases}
$$

denotes decision to invest in country $i$; Mills $s_{i}$ is the inverse Mills Ratio from the first stage, i.e. the non-selection hazard, $M K T_{i}$ a vector of three market factors for every country $i$, i.e. GDP (in current prices), real GDP per capita, and real GDP growth rate (source: World Development Indicators, WDI database), $M C R_{i}$ a vector of four macroeconomic control variables, i.e. the inflation rate of country $i$, trade openness of country $i$, the exchange rate (in local currency units per US $\$$, period average) of country $i$, and the gross secondary school enrollment rates (in percent) of country $i$ (source: WDI), $W G I_{i}$ a vector of the six Worldwide Governance Indicators (WGI) provided by the World Bank for every country $i$ : "Political stability/no violence", "rule of law", "regulatory quality", "voice and accountability", "control of corruption", "government effectiveness", respectively. Finally, $N T R_{i}$ denotes a vector of four variables that might reflect a resources seeking motive comprising total natural resources rents (in percent of GDP), agricultural raw materials exports (in percent of merchandise exports), fuel exports (in percent of total merchandise exports), ores and metals exports (in percent of total merchandise exports) for each country $i$, respectively (source: WDI).

Estimates of the first and second stage, i.e. (1) and (2), are reported in the penultimate ("Selection") and last ("Amount") column of Table 2, respectively. The first result to note is the insignificance of the inverse Mills Ratio coefficient. It suggests that COA binary choice and choice of volume decision need not to be treated separately. The fact that a Heckman selection model cannot reject a joint treatment of the dichotomous decision to go outward and the decision of the amount to spend makes us confident that focusing on large-scale COA ( $\geq$ US $\$ 100$ million) does not imply a severe bias. 
Table 2: Heckman selection model: Determinants of COA

(1)

\begin{tabular}{lrr} 
& Selection & Amount \\
\hline GDP (current million US \$) & 0.001 & -0.001 \\
GDP growth (annual perc.) & -0.148 & 1.054 \\
GDP per capita (constant 2005 US \$) & $-0.001^{*}$ & -0.003 \\
Inflation, GDP deflator (annual perc.) & $0.004^{*}$ & 0.003 \\
Openness: Ex/(Ex+Im) & 1.285 & 401.852 \\
Official exchange rate (LCU per US \$., period average) & $0.001^{*}$ & -0.001 \\
School enrolment, secondary (perc. gross) & -0.013 & 0.022 \\
WGI: Political Stability/No Violence & $-1.174^{* *}$ & 57.112 \\
WGI: Rule of Law & 1.429 & 0.250 \\
WGI: Regulatory Quality & $-1.637^{*}$ & 118.220 \\
WGI: Voice and Accountability & 0.110 & -59.395 \\
WGI: Control of Corruption & -1.041 & -137.988 \\
WGI: Government Effectiveness & $3.314^{* *}$ & 8.883 \\
Agricultural raw materials exports (perc. of merchandise exports) & 0.007 & -4.303 \\
Fuel exports (perc. of merchandise exports) & $0.046^{* * *}$ & 1.450 \\
Ores and metals exports (perc. of merchandise exports) & $0.045^{* * *}$ & $3.255^{*}$ \\
Inverse Mills Ratio & & 7.205 \\
Constant & -0.497 & -173.840 \\
\hline Observations & 94 & 36 \\
$p$-value for joint significance of $M K T_{i}$ & 0.192 & 0.913 \\
$p$-value for overall significance & 0.000 & 0.009 \\
\hline Deper & &
\end{tabular}

Dependent variable: 2005-2008 total of outward activity (US $\$$, scaled by host population).

Explanatory variables: $1992-2004$ averages. ${ }^{*} p<.10,{ }^{* *} p<.05,{ }^{* * *} p<.01$. 
Additionally, in both decision stage estimates, i.e. estimates of (1) and (2), none of the market factors turns out as statistically significant at a level of significance lower than 10 percent. The binary choice stage (1) estimate generates a significant coefficient with negative sign for the "political stability/no violence" variable, while for variable "government effectiveness" it produces a significant positive coefficient. ${ }^{3}$ The former finding, i.e. Chinese firms' preference for politically instable host countries, can be justified on the following major grounds (Cheung et al. 2012; Kolstad and Wiig 2012; Huang and Wang 2013; Guo et al. 2014). First, capital market imperfections provide state owned enterprises $(\mathrm{SOEs})^{4}$ in China access to funds at below market rates allowing them to invest in riskier locations. Secondly, SOEs' investment practices can be seen as driven by political affiliations and connections, for example, through approval systems and control mechanisms. Finally, it can be argued on path dependency grounds that Chinese firms are more familiar and comfortable with non-democratic and possibly less stable environments. Apart from this result, the two natural resource indicators fuel exports and ores and metal exports show the clearest positive impact in terms of statistical significance, while the two economic fundamentals inflation and exchange rate seem to play a minor role in terms of both size of coefficients and statistical significance. In stage (2) of the two-stage Heckman model estimate, we find only one weakly significant positive effect from the ores and metal exports variable.

Overall, our findings are suggestive for location and volume choice of COA in developing countries during our pre-crisis (2005-2008) period being not motivated by short-run business motives. They rather point to a combination of institutional and natural resource related considerations, which are both widely exogenous to short-run and medium-run economic fluctuations, being at work.

\footnotetext{
${ }^{3}$ This obviously needs not to be seen as contradictory as, for example, a violent dictator might be very efficient in providing infrastructure.

${ }^{4}$ In our sample for the pre-crisis period, the share of projects that have been run, at least in part, by SOEs is $96.88 \%$ for investments, $93.97 \%$ for contracts, and $95.88 \%$ for overall COA. As of 2009, the SOE-share in contracts has declined to an average $71.14 \%$, while the share of SOEs engaged in FDI remained stable at a very high level. In general, the private-public classification of Chinese firms is not easy and requires a case-by-case consideration (Ramasamy et al. 2012).
} 


\section{Identifying the differential crisis effect}

\subsection{Identification strategy}

To identify the differential crisis effect for developing countries witnessing COA and developing countries that did not host COA prior to the crisis, we slightly modify the basic difference-in-differences framework by also allowing for heterogeneity in dynamic effects between treatment and control group (Figure 2).

Figure 2: Average real GDP growth rates pre-crisis COA treatment vs. control group
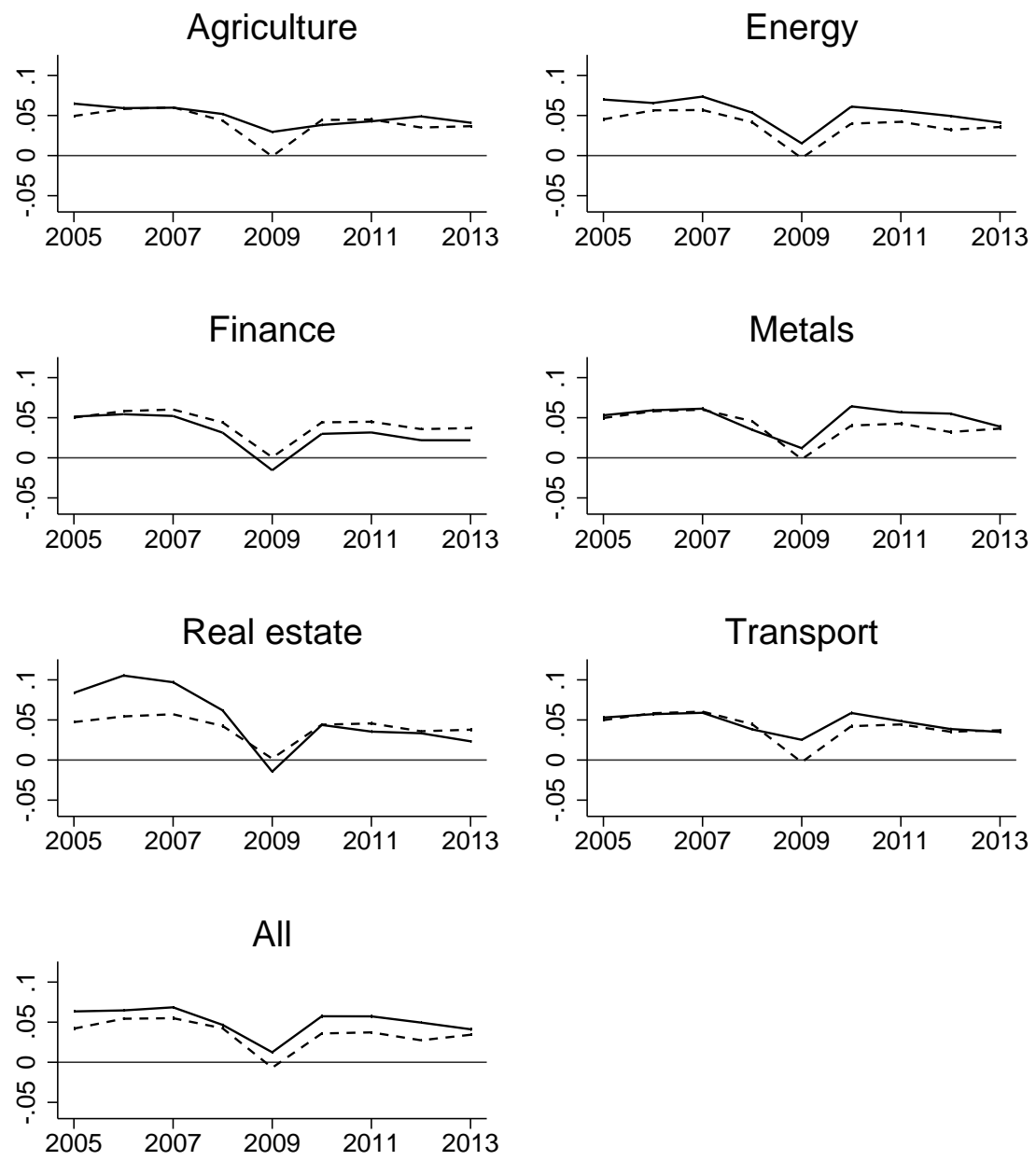

\footnotetext{
D Developing countries targeted by COA, 2005-2008
- Developing countries not targeted by COA, 2005-2008
} 
As can be seen from Figure 2, in the schedules for the metal, energy, and transport sector the average GDP growth rates of developing countries with pre-crisis COA (solid line) dip less deep than the corresponding series for developing countries without precrisis COA (dashed line). The same holds for the aggregate series of all sectors. This pattern is reversed in the real estate and finance sector. The agricultural industry is the only sector, where the two series get twisted as average GDP growth rates of developing countries with pre-crisis COA outperform their counterparts prior to 2006, for 2008 and 2009, and beyond 2011. The opposite applies for the years 2006 and 2010. Overall, the patterns shown in Figure 2 are suggestive for cushioning effects through COA depending on the targeted sector. Obviously, they also suggest to allow for flexible and heterogeneous dynamic effects across treatment and control group observations.

In detail, we estimate the following model

$$
y_{i t}=d_{t}+\delta_{i}+\sum_{\tau \in \mathcal{T}^{p r e}} \alpha_{\tau} \cdot d_{\tau} \cdot T R_{i}+\sum_{\tau \in \mathcal{T}^{\text {post }}} \alpha_{\tau} \cdot d_{\tau} \cdot T R_{i}+\varepsilon_{i t}
$$

where $y_{i t}$ denotes annual real GDP growth rate of country $i$ in year $t, d_{t}$ represent year fixed effects and $\delta_{i}$ country fixed effects, respectively. $T R_{i}$ is our treatment variable that is either defined as (a) years of total COA (i.e. FDI plus contracts) in treatment years in country $i$ or as (b) GDP share of total COA (i.e. FDI plus contracts) in treatment years (2005-2008) in country $i . \mathcal{T}^{\text {pre }}$ is the set of years before the crisis, $\mathcal{T}^{\text {post }}$ the set of years since/after the crisis, respectively.

This strategy allows us to test for and quantify the differential crisis effect through $\left\{\alpha_{\tau}\right\}_{\tau \in \mathcal{T}^{\text {pre }}}$ and $\left\{\alpha_{\tau}\right\}_{\tau \in \mathcal{T}^{\text {post }}}$, which are the interaction term coefficient vectors of interest. We estimate (3) with robust standard errors clustered at the country level.

\subsection{Findings and interpretation}

A summary of our estimates, averaging interaction term coefficients estimates $\left\{\alpha_{\tau}\right\}_{\tau \in \mathcal{T}^{\text {pre }}}$ and $\left\{\alpha_{\tau}\right\}_{\tau \in \mathcal{T} \text { post }}$, is given in Table 3 below. Detailed estimates are given in Table A.2 to A.15 in the Appendix. Note in Table $3 N^{T R}$ denotes number of treated countries and 
Table 3: Summary of interaction term models (3)

\begin{tabular}{|c|c|c|c|c|c|}
\hline & \multirow[b]{2}{*}{$N^{T R}$} & \multicolumn{2}{|c|}{$T R:$ Years } & \multicolumn{2}{|c|}{$T R:$ GDP $\%$} \\
\hline & & pre & post & pre & post \\
\hline \multicolumn{6}{|c|}{$C O A=F D I+C O$} \\
\hline All sectors & 40 & -0.004 & -0.003 & $0.001^{* * *}$ & $0.001^{* * *}$ \\
\hline Agriculture & 5 & $-0.011^{* * *}$ & $-0.010^{* * *}$ & $-0.031^{* * *}$ & $0.020^{* * *}$ \\
\hline Energy & 21 & -0.004 & -0.001 & $0.001^{* * *}$ & $0.001^{* * *}$ \\
\hline Finance & 1 & $-0.009^{* *}$ & $-0.015^{* * *}$ & $-0.017^{* *}$ & $-0.029^{* * *}$ \\
\hline Metals & 17 & -0.003 & $0.007^{* * *}$ & $0.004^{* *}$ & $0.016^{* * *}$ \\
\hline Real estate & 8 & -0.001 & $-0.047^{* * *}$ & $-0.031^{*}$ & $-0.154^{* * *}$ \\
\hline Transport & 12 & -0.004 & $0.005^{* *}$ & $-0.012^{* * *}$ & $-0.001^{*}$ \\
\hline \multicolumn{6}{|c|}{ Investment (FDI) } \\
\hline All sectors & 20 & -0.004 & $0.006^{*}$ & $0.001^{* * *}$ & $0.001^{* * *}$ \\
\hline Energy & 9 & -0.005 & 0.001 & $0.001^{* * *}$ & $0.001^{* * *}$ \\
\hline Finance & 1 & $-0.009^{* *}$ & $-0.015^{* * *}$ & $-0.017^{* *}$ & $-0.029^{* * *}$ \\
\hline Metals & 12 & -0.003 & 0.012 & $0.004^{* *}$ & $0.019^{* *}$ \\
\hline Real estate & 1 & $0.003^{* * *}$ & $-0.034^{* * *}$ & $0.087^{* * *}$ & $-0.911^{* * *}$ \\
\hline Transport & 1 & $0.019^{* * *}$ & $0.005^{* * *}$ & $0.503^{* * *}$ & $0.130^{* * *}$ \\
\hline \multicolumn{6}{|c|}{ Contracts (CO) } \\
\hline All sectors & 30 & -0.004 & -0.007 & -0.003 & -0.001 \\
\hline Agriculture & 5 & $-0.011^{* * *}$ & $-0.010^{* * *}$ & $-0.031^{* * *}$ & $0.020^{* * *}$ \\
\hline Energy & 16 & -0.003 & -0.001 & -0.001 & 0.001 \\
\hline Metals & 6 & -0.002 & $-0.005^{* * *}$ & $0.004^{* * *}$ & $0.015^{* * *}$ \\
\hline Real estate & 7 & -0.001 & $-0.048^{* *}$ & $-0.031^{*}$ & $-0.153^{* * *}$ \\
\hline Transport & 12 & -0.007 & $0.005^{*}$ & $-0.012^{* * *}$ & $-0.001^{*}$ \\
\hline
\end{tabular}

Notes: TR is either defined as years of Chinese activity ("Years") or average GDP share of Chinese activity ("GDP \%") in treatment period (2005-2008). pre and post denote averages of interaction term coefficients $\left\{\alpha_{\tau}\right\}$ in $\mathcal{T}^{\text {pre }}$ and $\mathcal{T}^{\text {post }}$, respectively. ${ }^{*} p<.10,{ }^{* *} p<.05,{ }^{* * *} p<.01$ correspond to $H_{0}:\left\{\alpha_{\tau}\right\}_{\tau \in \mathcal{T} \text { pre }}=0$ and $H_{0}:\left\{\alpha_{\tau}\right\}_{\tau \in \mathcal{T} \text { post }}=0$. 
"GDP \%" the share of total COA (i.e. FDI plus contracts) for each treated/host country, respectively. Due to outliers and data limitations some sectors have been dropped from the analysis (chemicals, technology, other).

For the interpretation let us start with column "post" focusing on years of COA first, i.e. with estimates reported in the fourth column, of Table 3. Obviously, there is no substantial effect in terms of size and significance if we look at the sectors' average coefficients ("All sectors"). On the other hand, exposure to COA clearly had a significant negative effect on the finance and real estate sectors' performance of host countries in the course of the crisis. This holds both for FDI alone as well as for total COA. Given the nature of the crisis triggered in the US subprime mortgage market, this is a reasonable finding. The agricultural sector with no FDI but Chinese contracting activity is estimated to have been negatively affected during and after the crisis by the length of exposure to this kind of pre-crisis COA. There is also evidence for some slight cushioning effect in the transportation sector that is significant at the 5 percent level. The pre-crisis COA exposure (in years) effects for the metal sectors in developing countries is fragile. It shows a significant negative sign for contracted engineering and construction services, a positive insignificant coefficient for FDI, and a slim and significant positive coefficient for total COA comprising both contracts and FDI.

Cushioning and adverse effects from pre-crisis COA considering the size of investments and contracts are reported in the last column of Table 3. Still, although significantly positive in the case of FDI, the average effects (referring to the "All sectors" lines) are negligible in terms of size. Again, COA - now measured as a share of a host country's GDP - had a significant negative effect on the finance and real estate sectors after the global spread of the crisis. This again holds both for FDI alone and for total COA. Considering the financial volume of COA benchmarked against domestic host standards, we now find a significant positive alleviating effect for contracts in the agricultural industry. In other words, there seems to be a trade-off. While long-term contracted exposure to COA bears aggravating effects, contracted services at large scale can cushion the adverse effects of a global slump. Considering the financial volume of COA also reveals significant 
cushioning effects in the energy and metals industries, and (although for FDI figures only) also in the transportation sector. As the metal sector is part of manufacturing, this to some extent confirms the Tong and Wei (2010) result of a cushioning effect of relatively illiquid pre-crisis FDI for manufacturing firms.

\subsection{Greenfield vs. M\&A}

According to Ashraf and Herzer (2014), the modes of entry literature emanates from the crowding-out strand of literature. The crowding-out of domestic investment argument is, for example, made in the context of firms financing their offshoring activity through borrowing in the host country and, thus, increasing the host countries' interest rates (Harrison and McMillian 2003). It is also made in the context of hosted firms crowding out domestic firms' market shares (Aitken and Harrison 1999), and in the context of hosted firms purchasing fewer inputs locally than crowded out domestic companies (RodríguezClare 1996). The more recent strand of theoretical literature does not come to a clear-cut projection for the effect of (the mode of) foreign entry on the host country welfare: While, for instance, the model of Kabiraj and Sinha (2015) predicts offshoring irrespective of the mode of entry to be harmful for the host country, in the model by Yokota and Chen (2012) the superiority of greenfield FDI depends on industry characteristics, that is, in particular, on the magnitude of technology spillovers and the sector specific relevance of technological advantages. With regard to capital formation, which is particularly relevant at business cycle frequencies, Mencinger (2003) and Herzer (2012) - arguing from the perspective of the host country - see a clear-cut disadvantage of M\&A compared to greenfield activity. Recently, also Ashraf and Herzer (2014) for a sample of 100 developing countries find no significant contribution to domestic capital formation through M\&As and only a slim net positive effect through greenfield (GF-)FDI. However, their estimates do not consider potential industry specific effects.

In our first specification we focus on pre-crisis Chinese outbound FDI that we discriminate intra-treatment-group between GF- and M\&A-FDI activity between 2005-2008, 
i.e. prior to the crisis: ${ }^{5}$

$$
\begin{aligned}
y_{i t}=d_{t}+\delta_{i}+ & \sum_{\tau \in \mathcal{T}^{p r e}} \alpha_{\tau}^{G F} \cdot d_{\tau} \cdot T R_{i}^{G F}+\sum_{\tau \in \mathcal{T}^{\text {post }}} \alpha_{\tau}^{G F} \cdot d_{\tau} \cdot T R_{i}^{G F}+ \\
& \sum_{\tau \in \mathcal{T}^{\text {pre }}} \alpha_{\tau}^{M A} \cdot d_{\tau} \cdot T R_{i}^{M A}+\sum_{\tau \in \mathcal{T}^{\text {post }}} \alpha_{\tau}^{M A} \cdot d_{\tau} \cdot T R_{i}^{M A}+\varepsilon_{i t}
\end{aligned}
$$

In our second joint-specification, we consider as a third additional treatment-class also contracts, which we indicate with a superscript $C O$ :

$$
\begin{aligned}
y_{i t}=d_{t}+\delta_{i}+ & \sum_{\tau \in \mathcal{T}^{\text {pre }}} \alpha_{\tau}^{G F} \cdot d_{\tau} \cdot T R_{i}^{G F}+\sum_{\tau \in \mathcal{T}^{\text {post }}} \alpha_{\tau}^{G F} \cdot d_{\tau} \cdot T R_{i}^{G F}+ \\
& \sum_{\tau \in \mathcal{T}^{\text {pre }}} \alpha_{\tau}^{M A} \cdot d_{\tau} \cdot T R_{i}^{M A}+\sum_{\tau \in \mathcal{T}^{\text {post }}} \alpha_{\tau}^{M A} \cdot d_{\tau} \cdot T R_{i}^{M A}+ \\
& \sum_{\tau \in \mathcal{T}^{\text {pre }}} \alpha_{\tau}^{C O} \cdot d_{\tau} \cdot T R_{i}^{C O}+\sum_{\tau \in \mathcal{T}^{\text {post }}} \alpha_{\tau}^{C O} \cdot d_{\tau} \cdot T R_{i}^{C O}+\varepsilon_{i t} .
\end{aligned}
$$

Note in both specifications (4) and (5), the conceptional logics of treatment variables is the same as in the preceding section, i.e. for $T R$ we use either a duration-measure ("years of Chinese activity") or a volume-measure ("GDP share of Chinese activity") for the pre-crisis period from 2005 to 2008. However, in contrast to equation (3) there is now more than one treatment dimension. These bivariate (4) or trivariate (5) treatment dimensions are estimated jointly, such that the reference case is an economy without any of the considered treatments, respectively. All bivariate or trivariate treatments are defined at the aggregate level or as either a pure energy sector or a pure metal sector treatment. Unfortunately, we are unable to isolate also the separate effects in the other four sectors analyzed in the preceding section. This is due to the fact that for the remaining industries each type of treatment does not exist —at least, once- for our sample. For example, there is no developing country prior to 2009, where Chinese firms realized a large-scale GF-FDI in the transport sector.

Estimation results are shown in Table 4, where rows of estimated coefficients refer to specification (4) and (5), respectively. Coefficient estimates in columns $G F$, MA, and $C O$ represent the average post-crisis impact of one additional treatment unit (i.e. either

\footnotetext{
${ }^{5}$ We identify the nature (GF vs. M $\& A$ ) of a project on the basis of information provided in the CGIT database supplemented with case-based company information.
} 
Table 4: Greenfield vs. M\&A, average interaction coefficients 2009-2013

\begin{tabular}{|c|c|c|c|c|c|}
\hline & $G F$ & $M A$ & $G F-M A$ & $C O$ & $C O-M A$ \\
\hline \multicolumn{6}{|l|}{$T R:$ Years } \\
\hline \multicolumn{6}{|l|}{ Sectors: All } \\
\hline Eq. (4): FDI only & $0.022^{* *}$ & 0.857 & -0.835 & & \\
\hline Eq. (5): FDI and contracts & 0.831 & 0.969 & -0.137 & -0.871 & -1.840 \\
\hline \multicolumn{6}{|l|}{ Sector: Energy } \\
\hline Eq. (4): FDI only & $1.090^{* * *}$ & $-0.598^{*}$ & 1.688 & & \\
\hline Eq. (5): FDI and contracts & $1.491^{* *}$ & $-0.425^{* * *}$ & 1.916 & -0.345 & 0.079 \\
\hline \multicolumn{6}{|l|}{ Sector: Metals } \\
\hline Eq. (4): FDI only & $0.241^{* * *}$ & $2.452^{* *}$ & -2.238 & & \\
\hline Eq. (5): FDI and contracts & $0.237^{* * *}$ & $2.433^{* *}$ & -2.196 & $-0.319^{* * *}$ & -2.752 \\
\hline \multicolumn{6}{|l|}{$T R:$ GDP $\%$} \\
\hline \multicolumn{6}{|l|}{ Sectors: All } \\
\hline Eq. (4): FDI only & $0.073^{* * *}$ & $0.872^{*}$ & -0.799 & & \\
\hline Eq. (5): FDI and contracts & $0.083^{* * *}$ & $0.881^{*}$ & -0.798 & -0.417 & -1.298 \\
\hline \multicolumn{6}{|l|}{ Sector: Energy } \\
\hline Eq. (4): FDI only & $0.066^{* * *}$ & $-0.791^{* * *}$ & $0.857^{* *}$ & & \\
\hline Eq. (5): FDI and contracts & $0.066^{* * *}$ & $-0.768^{* * *}$ & $0.834^{* *}$ & $-0.151^{*}$ & 0.618 \\
\hline \multicolumn{6}{|l|}{ Sector: Metals } \\
\hline Eq. (4): FDI only & $1.028^{* * *}$ & $4.559^{* * *}$ & -3.531 & & \\
\hline Eq. (5): FDI and contracts & $0.938^{* * *}$ & $4.567^{* * *}$ & -3.628 & $0.805^{* * *}$ & -3.761 \\
\hline
\end{tabular}

${ }^{*} p<.10,{ }^{* *} p<.05,{ }^{* * *} p<.01$. 
of one additional year or of one additional percentage point) for the respective pre-crisis treatment category. For example, the first entry (from the left) in the first row (column $G F)$, i.e. 0.022 , indicates that one additional year of Chinese pre-crisis GF-FDI is, on average, associated with an increase of the GDP growth rate by 0.022 percentage points without a sectoral identification of the treatment.

The asterisks ascribed to coefficients displayed in columns $G F, M A$, and $C O$ in Table 4 refer to joint significance tests of the post-crisis interaction terms in either specification (4) or (5). ${ }^{6}$ Asterisks in the $G F-M A$ and $C O-M A$ columns denote significant differences of average post-crisis interactions. Column GF-MA measures how much Chinese pre-crisis GF-FDI outperforms corresponding M\&A-FDI activity in terms of attenuating adverse cyclical growth effects during and after the Great Recession. Obviously, our results indicate that GF-FDI (as opposed to M\&As) shows this relative advantage of a cushioning property for the energy industry only. In this sector, M\&A-treatment effects are throughout estimated with a negative sign and sizable in absolute terms. The opposite (in terms of signs of estimated coefficients) applies for the metals industry. However, the difference between GF- and M\&A-FDI effects is estimated as statistically not different from zero. Similarly, contracted services are not found to bear a relative attenuation-potential advantage over M\&As.

\subsection{Robustness analysis}

In the following, we consider a more flexible and more full-fledged difference- in-differences specification. It is aimed to check our results for robustness by benchmarking COA against rest-of-world offshoring activity. However, due to data limitations, in particular, with regard to rest-of-world contracted engineering and construction services our robustness analysis is restricted to outbound FDI.

\footnotetext{
${ }^{6}$ Note, this is why smaller coefficient estimates in absolute terms can be estimated as more significantly different to zero than coefficient estimates that are larger in size and corresponding to variables measured at the same scale. In these cases, significant positive and significant negative effects attributable to single years might compensate each other.
} 
Our benchmarking strategy is summarized in Figure 3 and formalized in the following specification:

$$
\begin{gathered}
y_{i t}=\sum_{\Psi \in P R E, C R I, P O S T}\left[\Psi_{t} \times\left(\alpha^{\Psi}+\beta^{\Psi} \cdot F D I_{i t}^{C H N}+\theta^{\Psi} \cdot \sum_{r=2005}^{t-1} F D I_{i r}^{C H N}+\right.\right. \\
\left.\left.\gamma^{\Psi} \cdot F D I_{i t}^{\overline{C H N}}+\phi^{\Psi} \cdot \sum_{r=1998}^{t-1} F D I_{i r}^{\overline{C H N}}\right)\right]+ \\
\eta \cdot F D I_{i t}^{\overline{C H N}}+\zeta \cdot \sum_{r=1998}^{t-1} F D I_{i r}^{\overline{C H N}}+\text { Controls }_{i t}^{\prime} \lambda+\delta_{i}+\varepsilon_{i t},
\end{gathered}
$$

where $F D I_{i t}^{C H N}$ denotes developing country $i$ 's large-scale CFDI inflow in year $t$ (source: CGIT), as a share of its GDP. $F D I_{i t}^{\overline{C H N}}$ is - again as a share of GDP - all FDI that is targeted at country $i$ in year $t$ from the rest of the world, i.e. the annual FDI inflow net of Chinese large-scale FDI (sources: CGIT and WDI).

To allow for dynamic externalities, equation (6) contains, besides the contemporaneous FDI inflow variables, cumulative stocks of past FDI inflows — originating both from China, $\sum_{r=2005}^{t-1} F D I_{i r}^{C H N}$, and from the rest of the world, $\sum_{r=1998}^{t-1} F D I_{i r}^{\overline{C H N}}$. While accumulation of large-scale FDI from China did not start until 2005, rest-of-world FDI is included back to the year 1998 .

Figure 3: Time scheme: Robustness analysis

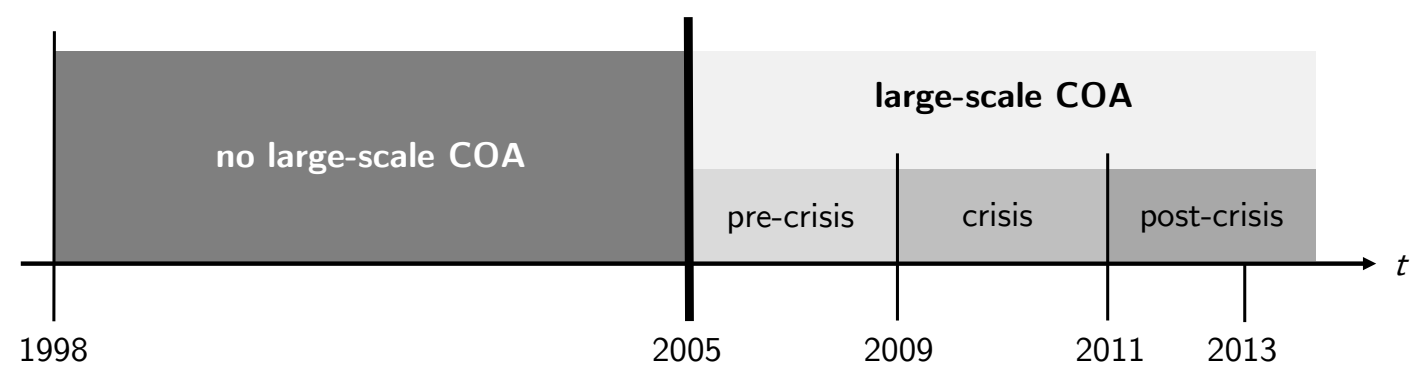

Differential effects are estimated separately for the pre-crisis period (PRE, 2005-2008), the peak years of the crisis (CRI, 2009-2010), and the emerging recovery phase (POST, 2011-2013). The corresponding model components, which are addressed by index $\Psi$, indicate the respective differences to the reference period of no large-scale COA. 
Table 5: Estimated parameters from robustness analysis model (6)

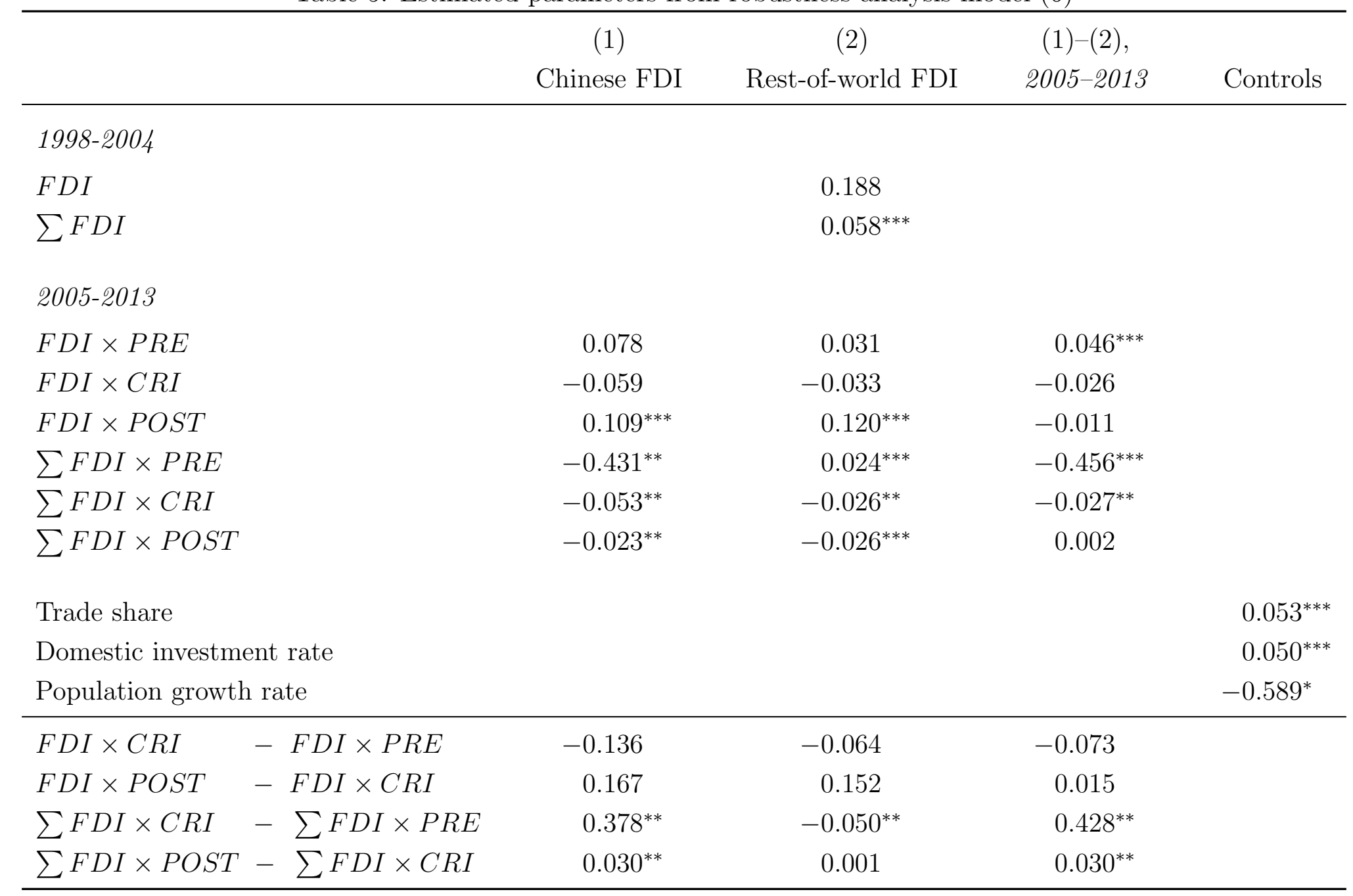

Notes: Dependent variable: Real GDP per capita growth rate. FDI: FDI share in country's GDP. PRE: 2005-2008; CRI: 2009-2010; POST: 2011-2013. Estimates for country fixed effects and stand-alone period dummies (PRE, CRI, POST) are not reported.

In panel "2005-2013", parameters in column (2) are sums: FDI or $\sum F D I$ coefficient + respective period interaction coefficient. $N=1406, R^{2}=0.166 .{ }^{*} p<.10,{ }^{* *} p<.05,{ }^{* * *} p<.01$. 
Since we estimate model (6) with data from 1998 to 2013 -also covering the pre-2005 era of no large-scale COA in developing countries - rest-of-world variables are included as additional stand-alone, i.e. non-interacted, regressors. As further explanatories for annual GDP growth $\left(y_{i t}\right)$, that provide variation at the country-year level, we consider three macroeconomic indicators: trade share, domestic investment rate, and population growth rate (source: WDI). As before, $\delta_{i}$ are country fixed effects and $\varepsilon_{i t}$ is the usual error term. Regression results are displayed in Table 5. The macroeconomic control variables shown in the ultimate column turn out statistically significant and with the expected signs. The other parameter estimates pertaining to model (6) are organized in columns and rows, distinguishing contemporaneous and past FDI treatment impacts from Chinese and rest-of-world origins in different periods of time. Contemporaneous CFDI does not have a significant influence before the crisis and in the peak years of 2009 and 2010 . However, before and during the crisis, cumulative CFDI is found to bear negative effects - both in absolute terms and compared to cumulative FDI from the rest of the world. This aggravation potential of cumulative CFDI, though, diminishes substantially during the crisis vis-à-vis before (0.378). The opposite applies to the rest-of-world cumulative FDI impact which slightly deteriorates as soon as the Great Recession starts to spread $(-0.050)$.

\section{Conclusion}

In this study we analyzed sectoral data on Chinese large-scale investment and overseas project contracts by sector prior to and after the spread of the "Great Recession" in a difference-in-differences framework. Examining first the pre-crisis determinants of falling into our treatment group, i.e. hosting Chinese outward activity prior to 2008, only institutional and natural resource variables turn out as significant covariates. Both factors are widely exogenous at relevant business cycle frequencies. In our second set of estimates, we find that, on average, Chinese outward activity did not increase vulnerability to the global recession. However, both the sectoral targeting and the size of the pre-crisis en-

gagement are found to play a crucial role. While Chinese outward engagement in clearly 
to financial markets tied sectors implied an aggravation, substantial pre-crisis investment in the energy, metals and transportation industries implied an attenuation of the slump.

Our study complements and goes beyond the findings of Tong and Wei (2010), who focus on the manufacturing sector, in that it also finds significant cushioning effects in the non-manufacturing energy and transportation industries. For the agricultural sectors we find a trade-off. While long-term contracted exposure to Chinese outward activity implies aggravating effects, large contracted services in domestic product's terms can cushion the adverse effects of an international crisis.

With regard to different modes of entry, our results indicate that, at least, for the energy sector (voluminous) Chinese pre-crisis greenfield FDI as opposed to M\&A-FDI holds the potential of cushioning global recessionary tendencies affecting cyclical growth in developing countries.

\section{References}

[1] Aitken, B.J. and A.E. Harrison (1999), Do domestic firms benefit from direct foreign investment? Evidence from Venezuela, American Economic Review 89, 605-618.

[2] Alfaro, L.A., Chanda, A., Kalmli-Ozcan, S., and S. Sayek (2004), FDI and economic growth: The role of local financial markets, Journal of International Economics 64, 89-112.

[3] Amighini, A., Rabellotti, R., and M. Sanfilippo (2013), China's outward FDI: An industry-level analysis of host country determinants, Froniers of Economics in China 8, 309-336.

[4] Ashraf, A. and D. Herzer (2014), The effect of greenfield investment and M\&As on domestic investment in developing countries, Applied Economics Letters 21, 997-1000.

[5] Beugelsdijk, S., Smeets, R., and R. Zwinkels (2008), The impact of horizontal and vertical FDI on host's country economic growth, International Business Review 17, $452-472$. 
[6] Blanchard, O., Das, M., and H. Faruque (2010), The initial impact of the crisis on emerging market countries, Brookings Papers on Economic Activity 41, 263-307.

[7] Blonigen, B.A. and M. Wang (2004), Inappropriate pooling of wealthy and poor countries in empirical FDI studies, NBER Working Paper, No. 10378.

[8] Borensztein, E., De Gregorio, J., and J.W. Lee (1998), How does foreign direct investment affect growth?, Journal of International Economics 45, 115-135.

[9] Brems, H. (1970), A growth model of international direct investment, American Economic Review 60, 320-331.

[10] Buchanan, B.G., Le, Q.V., and M. Rishi (2012), Foreign direct investment and institutional quality: Some empirical evidence, International Review of Financial Analysis $21,81-89$.

[11] Buckley, P.J., Clegg, L.J., Cross, A.R., Liu, X., Voss, H., and P. Zheng (2007), The determinants of Chinese outward foreign direct investment, Journal of International Business Studies 38, 499-518.

[12] Campos, N.F. and Y. Kinoshita (2002), Foreign direct investment as technology transferred: Some panel evidence from the transition economies, Manchester School 70, $398-419$.

[13] Cheung, Y.-W. and X. Qian (2009), Empirics of China's outward direct investment, Pacific Economic Review 14, 312-341.

[14] Cheung, Y.-W., de Haan, J., Qian, X., and S. Yu (2012), China's outward direct investment in Africa, Review of International Economics 20, 201-220.

[15] Claessens, S., Tong, H., and S.-J. Wei (2012), From the financial crisis to the real economy: Using firm-level data to identify transmission channels, Journal of International Economics 88, 375-387.

[16] De Mello, L.R. (1997), Foreign direct investment in developing countries and growth: A selective survey, Journal of Development Studies 34, 1-34.

[17] Dreher, A. and A. Fuchs (2015), Rogue aid? The determinants of China's aid allocation, forthcoming in Canadian Journal of Economics.

[18] Görg, H. and D. Greenaway (2004), Much ado about nothing? Do domestic firms really benefit from foreign direct investment?, World Bank Research Observer 19, 171-197. 
[19] Guo, J.-j., Wang, G.-c., and C.-h. Tung (2014), Do China's outward direct investors prefer countries with high political risk? An international and empirical comparison, China \& World Economy 22, 22-43.

[20] Harrison, A.E. and M.S. McMillan (2003), Does foreign direct investment affect domestic credit constraints?, Journal of International Economics 61, 73-100.

[21] Henry, P.B. (2007), Capital account liberalization: Theory, evidence, and speculation, Journal of Economic Literature 45, 887-935.

[22] Herzer, D., Klasen, S., and F. Nowak-Lehmann D. (2008), In search of FDI-led growth in developing countries: The way forward, Economic Modelling 25, 793-810.

[23] Herzer, D. (2012), How does foreign direct investment really affect developing countries' growth?, Review of International Economics 20, 396-414.

[24] Huang, Y. and B. Wang (2011), Chinese outward direct investment: Is there a China Model?, China \&3 World Economy 19, 1-21.

[25] Huang, Y. and B. Wang (2013), Investing overseas without moving factories abroad: The case of Chinese outward direct investment, Asian Development Review 30, 85107.

[26] Javorcik, B.S. (2004), Does foreign direct investment increase the productivity of domestic firms? In search of spillovers through backward linkages, American Economic Review 94, 605-627.

[27] Kabiraj, T. and U.B. Sinha (2015), Foreign entry, acquisition target and host country welfare, Manchester School 83, 725-748.

[28] Kang, Y. and F. Jiang (2012), FDI location choice of Chinese multinationals in East and Southeast Asia: Traditional economic factors and institutional perspective, Journal of World Business 47, 45-53.

[29] Kinda, T. (2010), Investment climate and FDI in developing countries: Firm-level evidence, World Development 38, 498-513.

[30] Kolstad, I. and A. Wiig (2012), What determines Chinese outward FDI?, Journal of World Business 47, 26-34.

[31] Lin, P. and K. Saggi (2007), Multinational firms, exclusivity, and backward linkages, Journal of International Economics 71, 206-220.

[32] Luo, Y., Xue, Q., and B. Han (2010), How emerging market governments promote outward FDI: Experience from China, Journal of World Business 45, 68-79. 
[33] Markusen, J.R. and A.J. Venables (1999), Foreign direct investment as a catalyst for industrial development, European Economic Review 43, 335-356.

[34] Mencinger, J. (2003), Does foreign direct investment always enhance economic growth?, Kyklos 56, 491-508.

[35] Prasad, E.S., Rogoff, K., Wei, S.-J., and M.A. Kose (2003), Effects of globalization on developing countries: Some evidence, IMF Occasional Paper, No. 220.

[36] Ramasamy, B., Yeung, M., and S. Laforet (2012), China's outward foreign direct investment: Location choice and firm ownership, Journal of World Business 47, 1725.

[37] Rodríguez-Clare, A. (1996), Multinationals, linkages, and economic development, American Economic Review 86, 852-873.

[38] Rodrik, D. and A. Subramanian (2009), Why did financial globalization disappoint?, IMF Staff Papers 56, 112-138.

[39] Rosen, D.H. and T. Hanemann (2009), China's changing outbound foreign direct investment profile: Drivers and policy implications, Peterson Institute for International Economics Policy Brief, No. PB09-14.

[40] Scissors, D. (2013), China's steady global investment: American choices, Heritage Foundation Issue Brief, No. 3990.

[41] Scissors, D. (2015), China's outward investment healthy, puzzling, American Enterprise Institute Research Report, January 7.

[42] Stulz, R.M. (2005), The limits of financial globalization, Journal of Finance 60, 15951638.

[43] Tong, H. and S.-J. Wei (2010), The composition matters: Capital inflows and liquidity crunch during a global economic crisis, Review of Financial Studies 24, 2023-2052.

[44] Yokota, K. and K.-M. Chen (2012), R\&D spillovers and foreign market entry: Acquisition versus greenfield investment, International Economic Journal 26, 265-280. 


\section{Appendix}

Table A.1: Sample of developing countries

\begin{tabular}{|c|c|c|c|c|}
\hline Country & $C O A$ & $I N V$ & $C O$ & Remark \\
\hline Algeria & Yes & & Yes & \\
\hline Argentina & Yes & Yes & Yes & \\
\hline \multicolumn{5}{|l|}{ Armenia } \\
\hline Azerbaijan & Yes & & Yes & \\
\hline \multicolumn{5}{|l|}{ Bahrain } \\
\hline Bangladesh & Yes & & Yes & \\
\hline \multicolumn{5}{|l|}{ Barbados } \\
\hline Belarus & Yes & & Yes & \\
\hline \multicolumn{5}{|l|}{ Belize } \\
\hline \multicolumn{5}{|l|}{ Benin } \\
\hline Bolivia & Yes & & Yes & \\
\hline Bosnia and Herzegovina & Yes & & Yes & \\
\hline Botswana & Yes & & Yes & \\
\hline Brazil & Yes & Yes & Yes & \\
\hline Brunei & Yes & Yes & & \\
\hline Bulgaria & Yes & Yes & & \\
\hline \multicolumn{5}{|l|}{ Cabo Verde } \\
\hline Cameroon & Yes & Yes & Yes & \\
\hline Chile & Yes & Yes & & \\
\hline Colombia & Yes & Yes & Yes & \\
\hline \multicolumn{5}{|l|}{ Comoros } \\
\hline Costa Rica & Yes & & Yes & \\
\hline \multicolumn{5}{|l|}{ Croatia } \\
\hline Cuba & Yes & Yes & Yes & \\
\hline Côte d'Ivoire & Yes & & Yes & \\
\hline Dem. People's Rep. Korea & Yes & Yes & & Not used \\
\hline \multicolumn{5}{|l|}{ Dominica } \\
\hline \multicolumn{5}{|l|}{ Dominican Republic } \\
\hline Ecuador & Yes & Yes & Yes & \\
\hline Egypt & Yes & Yes & Yes & \\
\hline \multicolumn{5}{|l|}{ El Salvador } \\
\hline Equatorial Guinea & Yes & & Yes & Not in Heckman model \\
\hline \multicolumn{5}{|l|}{ Fiji } \\
\hline Gabon & Yes & & Yes & \\
\hline Georgia & Yes & Yes & Yes & \\
\hline Ghana & Yes & Yes & Yes & \\
\hline Grenada & & & & \\
\hline
\end{tabular}


Table A.1: Sample of developing countries (cont'ed)

\begin{tabular}{|c|c|c|c|c|}
\hline Country & $C O A$ & $I N V$ & $C O$ & Remark \\
\hline Guinea & Yes & Yes & Yes & \\
\hline \multicolumn{5}{|l|}{ Guinea-Bissau } \\
\hline Guyana & Yes & Yes & Yes & \\
\hline \multicolumn{5}{|l|}{ Honduras } \\
\hline Hungary & Yes & Yes & Yes & \\
\hline India & Yes & Yes & Yes & \\
\hline Indonesia & Yes & Yes & Yes & \\
\hline Iran & Yes & Yes & Yes & \\
\hline Jamaica & Yes & Yes & Yes & Not used \\
\hline Jordan & Yes & & Yes & \\
\hline Kazakhstan & Yes & Yes & Yes & \\
\hline Kenya & Yes & Yes & Yes & \\
\hline Kosovo & & & & Not in Heckman model \\
\hline Kyrgyz Republic & Yes & & Yes & \\
\hline \multicolumn{5}{|l|}{ Lebanon } \\
\hline \multicolumn{5}{|l|}{ Lithuania } \\
\hline Macedonia & Yes & & Yes & \\
\hline Malaysia & Yes & Yes & Yes & \\
\hline \multicolumn{5}{|l|}{ Maldives } \\
\hline Mauritius & Yes & Yes & Yes & \\
\hline Mexico & Yes & Yes & Yes & \\
\hline \multicolumn{5}{|l|}{ Moldova } \\
\hline Mongolia & Yes & Yes & & \\
\hline Montenegro & Yes & & Yes & Not in Heckman model \\
\hline Morocco & Yes & & Yes & \\
\hline Mozambique & Yes & Yes & Yes & \\
\hline Nicaragua & Yes & Yes & Yes & \\
\hline Niger & Yes & Yes & Yes & \\
\hline Nigeria & Yes & Yes & Yes & \\
\hline Oman & Yes & & Yes & \\
\hline Palau & & & & Not in Heckman model \\
\hline \multicolumn{5}{|l|}{ Panama } \\
\hline Papua New Guinea & Yes & Yes & Yes & \\
\hline \multicolumn{5}{|l|}{ Paraguay } \\
\hline Peru & Yes & Yes & & \\
\hline Philippines & Yes & Yes & Yes & \\
\hline Poland & Yes & Yes & Yes & \\
\hline Romania & Yes & & Yes & \\
\hline Russia & Yes & Yes & Yes & \\
\hline \multicolumn{5}{|l|}{ Samoa } \\
\hline Senegal & Yes & & Yes & \\
\hline
\end{tabular}


Table A.1: Sample of developing countries (cont'ed)

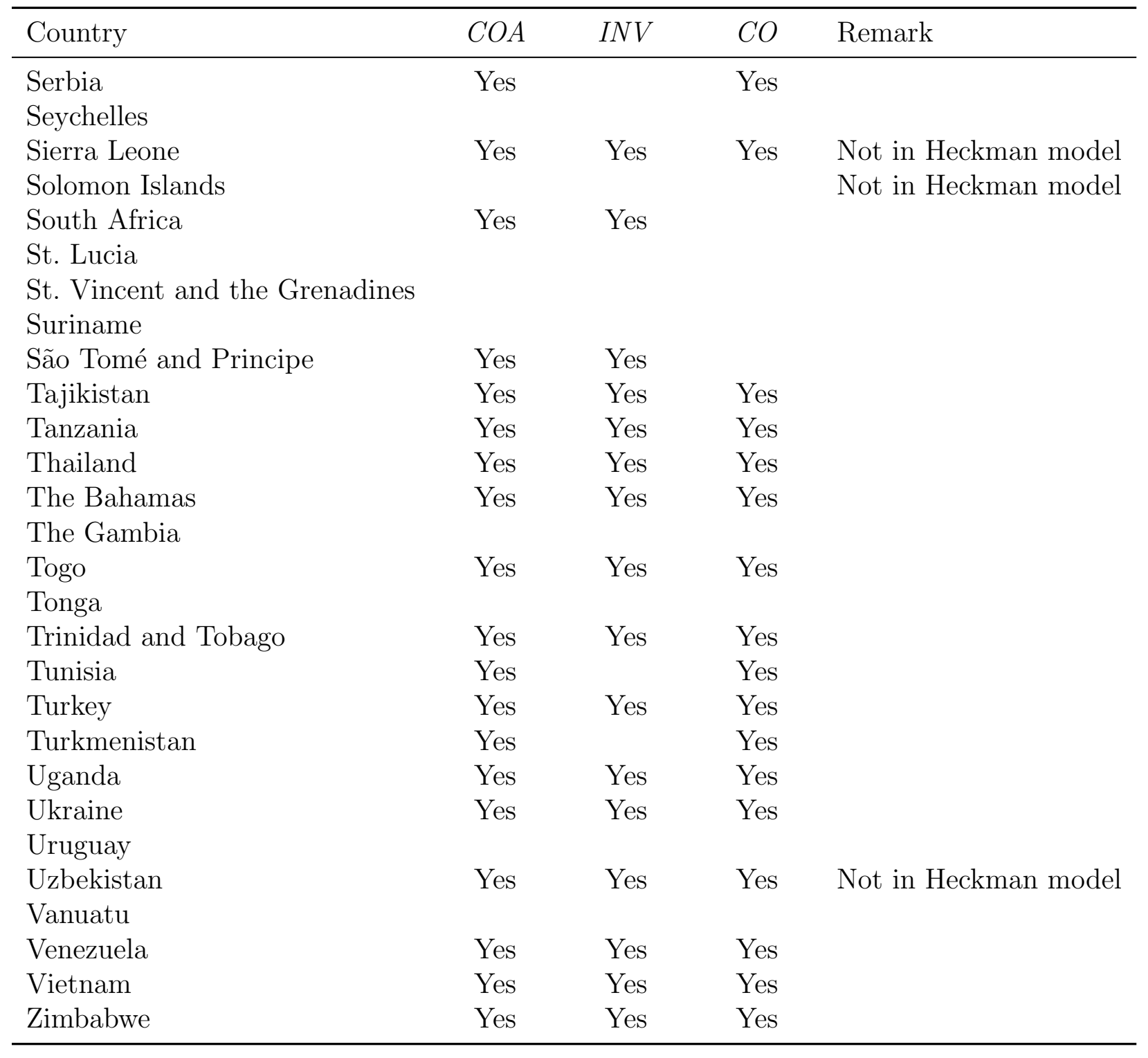


Table A.2: Sectors: All; Treatment (2005-2008): Years

\begin{tabular}{|c|c|c|c|}
\hline & $C O A$ & $F D I$ & $C O$ \\
\hline Year 2006 & $0.011^{* *}$ & $0.010^{* *}$ & $0.011^{* *}$ \\
\hline Year 2007 & $0.011^{* * *}$ & $0.011^{* * *}$ & $0.011^{* * *}$ \\
\hline Year 2008 & 0.001 & -0.001 & -0.001 \\
\hline Year 2009 & $-0.050^{* * *}$ & $-0.051^{* * *}$ & $-0.050^{* * *}$ \\
\hline Year 2010 & -0.006 & $-0.009^{*}$ & -0.004 \\
\hline Year 2011 & -0.003 & -0.007 & -0.002 \\
\hline Year 2012 & $-0.012^{* *}$ & $-0.015^{* * *}$ & $-0.010^{* *}$ \\
\hline Year 2013 & -0.006 & $-0.012^{* *}$ & -0.006 \\
\hline Year $2006 \times$ Treatment $(2005-2008)$ & -0.003 & -0.001 & -0.004 \\
\hline Year $2007 \times$ Treatment $(2005-2008)$ & -0.002 & -0.002 & -0.002 \\
\hline Year 2008 × Treatment (2005-2008) & -0.007 & -0.009 & -0.007 \\
\hline Year $2009 \times$ Treatment $(2005-2008)$ & 0.001 & 0.007 & 0.001 \\
\hline Year $2010 \times$ Treatment $(2005-2008)$ & 0.001 & $0.012^{*}$ & -0.004 \\
\hline Year $2011 \times$ Treatment $(2005-2008)$ & -0.003 & 0.007 & -0.009 \\
\hline Year $2012 \times$ Treatment (2005-2008) & -0.002 & 0.007 & -0.007 \\
\hline Year $2013 \times$ Treatment $(2005-2008)$ & $-0.010^{* *}$ & -0.003 & $-0.014^{* *}$ \\
\hline Constant & $0.050^{* * *}$ & $0.050^{* * *}$ & $0.050^{* * *}$ \\
\hline$R^{2}$ & 0.077 & 0.076 & 0.074 \\
\hline
\end{tabular}

${ }^{*} p<.10,{ }^{* *} p<.05,{ }^{* * *} p<.01$.

Table A.3: Sectors: All; Treatment (2005-2008): GDP \%

\begin{tabular}{|c|c|c|c|}
\hline & $C O A$ & $F D I$ & $C O$ \\
\hline Year 2006 & $0.010^{* *}$ & $0.010^{* *}$ & $0.012^{* *}$ \\
\hline Year 2007 & $0.011^{* * *}$ & $0.010^{* * *}$ & $0.011^{* * *}$ \\
\hline Year 2008 & -0.005 & -0.004 & -0.004 \\
\hline Year 2009 & $-0.050^{* * *}$ & $-0.050^{* * *}$ & $-0.050^{* * *}$ \\
\hline Year 2010 & -0.007 & -0.007 & -0.005 \\
\hline Year 2011 & -0.006 & -0.006 & -0.006 \\
\hline Year 2012 & $-0.015^{* * *}$ & $-0.014^{* * *}$ & $-0.013^{* * *}$ \\
\hline Year 2013 & $-0.012^{* *}$ & $-0.012^{* *}$ & $-0.011^{* *}$ \\
\hline Year $2006 \times$ Treatment $(2005-2008)$ & -0.001 & 0.001 & -0.007 \\
\hline Year $2007 \times$ Treatment $(2005-2008)$ & $-0.001^{* * *}$ & $-0.001^{* * *}$ & -0.002 \\
\hline Year $2008 \times$ Treatment $(2005-2008)$ & $0.001^{* * *}$ & $0.001^{* * *}$ & -0.001 \\
\hline Year $2009 \times$ Treatment $(2005-2008)$ & 0.001 & 0.001 & 0.001 \\
\hline Year $2010 \times$ Treatment $(2005-2008)$ & $0.001^{* * *}$ & $0.001^{* * *}$ & -0.002 \\
\hline Year $2011 \times$ Treatment $(2005-2008)$ & -0.001 & -0.001 & 0.001 \\
\hline Year $2012 \times$ Treatment (2005-2008) & $0.002^{* * *}$ & $0.002^{* * *}$ & 0.001 \\
\hline Year $2013 \times$ Treatment $(2005-2008)$ & 0.001 & 0.001 & -0.004 \\
\hline Constant & $0.050^{* * *}$ & $0.050^{* * *}$ & $0.050^{* * *}$ \\
\hline$R^{2}$ & 0.078 & 0.076 & 0.071 \\
\hline
\end{tabular}

${ }^{*} p<.10,{ }^{* *} p<.05,{ }^{* * *} p<.01$. 
Table A.4: Sector: Agriculture; Treatment (2005-2008): Years

\begin{tabular}{|c|c|c|c|}
\hline & $C O A$ & $F D I$ & $C O$ \\
\hline Year 2006 & $0.011^{* *}$ & & $0.011^{* *}$ \\
\hline Year 2007 & $0.011^{* * *}$ & & $0.011^{* * *}$ \\
\hline Year 2008 & -0.004 & & -0.004 \\
\hline Year 2009 & $-0.050^{* * *}$ & & $-0.050^{* * *}$ \\
\hline Year 2010 & -0.005 & & -0.005 \\
\hline Year 2011 & -0.005 & & -0.005 \\
\hline Year 2012 & $-0.013^{* * *}$ & & $-0.013^{* * *}$ \\
\hline Year 2013 & $-0.012^{* *}$ & & $-0.012^{* *}$ \\
\hline Year $2006 \times$ Treatment $(2005-2008)$ & $-0.019^{* *}$ & & $-0.019^{* *}$ \\
\hline Year $2007 \times$ Treatment $(2005-2008)$ & $-0.014^{*}$ & & $-0.014^{*}$ \\
\hline Year $2008 \times$ Treatment $(2005-2008)$ & -0.001 & & -0.001 \\
\hline Year $2009 \times$ Treatment $(2005-2008)$ & 0.003 & & 0.003 \\
\hline Year $2010 \times$ Treatment $(2005-2008)$ & -0.022 & & -0.022 \\
\hline Year $2011 \times$ Treatment $(2005-2008)$ & -0.016 & & -0.016 \\
\hline Year $2012 \times$ Treatment (2005-2008) & -0.004 & & -0.004 \\
\hline Year 2013 × Treatment (2005-2008) & -0.014 & & -0.014 \\
\hline Constant & $0.050^{* * *}$ & & $0.050^{* * *}$ \\
\hline$R^{2}$ & 0.071 & & 0.071 \\
\hline
\end{tabular}

${ }^{*} p<.10,{ }^{* *} p<.05,{ }^{* * *} p<.01$.

Table A.5: Sector: Agriculture; Treatment (2005-2008): GDP \%

\begin{tabular}{|c|c|c|c|}
\hline & $C O A$ & $F D I$ & $\mathrm{CO}$ \\
\hline Year 2006 & $0.010^{* *}$ & & $0.010^{* *}$ \\
\hline Year 2007 & $0.010^{* * *}$ & & $0.010^{* * *}$ \\
\hline Year 2008 & -0.004 & & -0.004 \\
\hline Year 2009 & $-0.050^{* * *}$ & & $-0.050^{* * *}$ \\
\hline Year 2010 & -0.006 & & -0.006 \\
\hline Year 2011 & -0.005 & & -0.005 \\
\hline Year 2012 & $-0.013^{* * *}$ & & $-0.013^{* * *}$ \\
\hline Year 2013 & $-0.012^{* *}$ & & $-0.012^{* *}$ \\
\hline Year 2006 × Treatment (2005-2008) & $-0.070^{* * *}$ & & $-0.070^{* * *}$ \\
\hline Year $2007 \times$ Treatment $(2005-2008)$ & $-0.049^{* *}$ & & $-0.049^{* *}$ \\
\hline Year 2008 × Treatment (2005-2008) & 0.027 & & 0.027 \\
\hline Year $2009 \times$ Treatment $(2005-2008)$ & $0.124^{* * *}$ & & $0.124^{* * *}$ \\
\hline Year $2010 \times$ Treatment $(2005-2008)$ & -0.008 & & -0.008 \\
\hline Year $2011 \times$ Treatment $(2005-2008)$ & -0.025 & & -0.025 \\
\hline Year $2012 \times$ Treatment $(2005-2008)$ & 0.009 & & 0.009 \\
\hline Year 2013 × Treatment $(2005-2008)$ & 0.001 & & 0.001 \\
\hline Constant & $0.050^{* * *}$ & & $0.050^{* * *}$ \\
\hline$R^{2}$ & 0.066 & & 0.066 \\
\hline
\end{tabular}

${ }^{*} p<.10,{ }^{* *} p<.05,{ }^{* * *} p<.01$. 
Table A.6: Sector: Energy; Treatment (2005-2008): Years

\begin{tabular}{|c|c|c|c|}
\hline & $C O A$ & $F D I$ & $C O$ \\
\hline Year 2006 & $0.011^{* *}$ & $0.010^{* *}$ & $0.011^{* *}$ \\
\hline Year 2007 & $0.011^{* * *}$ & $0.011^{* * *}$ & $0.010^{* * *}$ \\
\hline Year 2008 & -0.002 & -0.003 & -0.002 \\
\hline Year 2009 & $-0.051^{* * *}$ & $-0.050^{* * *}$ & $-0.052^{* * *}$ \\
\hline Year 2010 & -0.007 & -0.007 & -0.007 \\
\hline Year 2011 & -0.005 & -0.006 & -0.005 \\
\hline Year 2012 & $-0.013^{* * *}$ & $-0.013^{* * *}$ & $-0.013^{* * *}$ \\
\hline Year 2013 & $-0.010^{* *}$ & $-0.011^{* *}$ & $-0.010^{* *}$ \\
\hline Year $2006 \times$ Treatment (2005-2008) & -0.004 & -0.001 & -0.005 \\
\hline Year $2007 \times$ Treatment $(2005-2008)$ & -0.001 & -0.006 & 0.001 \\
\hline Year $2008 \times$ Treatment $(2005-2008)$ & -0.006 & -0.009 & -0.005 \\
\hline Year $2009 \times$ Treatment $(2005-2008)$ & 0.004 & -0.001 & 0.009 \\
\hline Year $2010 \times$ Treatment $(2005-2008)$ & 0.003 & 0.006 & 0.002 \\
\hline Year $2011 \times$ Treatment $(2005-2008)$ & -0.002 & 0.003 & -0.003 \\
\hline Year $2012 \times$ Treatment $(2005-2008)$ & -0.002 & 0.002 & -0.002 \\
\hline Year $2013 \times$ Treatment (2005-2008) & -0.008 & -0.009 & -0.009 \\
\hline Constant & $0.050^{* * *}$ & $0.050^{* * *}$ & $0.050^{* * *}$ \\
\hline$R^{2}$ & 0.085 & 0.080 & 0.086 \\
\hline
\end{tabular}

${ }^{*} p<.10,{ }^{* *} p<.05,{ }^{* * *} p<.01$.

Table A.7: Sector: Energy; Treatment (2005-2008): GDP \%

\begin{tabular}{|c|c|c|c|}
\hline & $C O A$ & $F D I$ & $C O$ \\
\hline Year 2006 & $0.010^{* *}$ & $0.010^{* *}$ & $0.011^{* *}$ \\
\hline Year 2007 & $0.010^{* * *}$ & $0.010^{* * *}$ & $0.010^{* * *}$ \\
\hline Year 2008 & -0.004 & -0.004 & -0.004 \\
\hline Year 2009 & $-0.050^{* * *}$ & $-0.050^{* * *}$ & $-0.050^{* * *}$ \\
\hline Year 2010 & -0.007 & -0.006 & -0.006 \\
\hline Year 2011 & -0.006 & -0.005 & -0.006 \\
\hline Year 2012 & $-0.014^{* * *}$ & $-0.014^{* * *}$ & $-0.014^{* * *}$ \\
\hline Year 2013 & $-0.012^{* *}$ & $-0.012^{* *}$ & $-0.012^{* *}$ \\
\hline Year $2006 \times$ Treatment $(2005-2008)$ & -0.001 & 0.001 & -0.005 \\
\hline Year $2007 \times$ Treatment $(2005-2008)$ & $-0.001^{* * *}$ & $-0.001^{* * *}$ & 0.001 \\
\hline Year $2008 \times$ Treatment (2005-2008) & $0.001^{* * *}$ & $0.001^{* * *}$ & 0.003 \\
\hline Year $2009 \times$ Treatment $(2005-2008)$ & 0.001 & -0.001 & 0.002 \\
\hline Year $2010 \times$ Treatment $(2005-2008)$ & $0.001^{* * *}$ & $0.001^{* * *}$ & -0.001 \\
\hline Year $2011 \times$ Treatment $(2005-2008)$ & -0.001 & $-0.001^{* * *}$ & 0.005 \\
\hline Year $2012 \times$ Treatment (2005-2008) & $0.002^{* * *}$ & $0.002^{* * *}$ & 0.003 \\
\hline Year $2013 \times$ Treatment $(2005-2008)$ & 0.001 & 0.001 & -0.002 \\
\hline Constant & $0.050^{* * *}$ & $0.050^{* * *}$ & $0.050^{* * *}$ \\
\hline$R^{2}$ & 0.077 & 0.077 & 0.080 \\
\hline
\end{tabular}

${ }^{*} p<.10,{ }^{* *} p<.05,{ }^{* * *} p<.01$. 
Table A.8: Sector: Finance; Treatment (2005-2008): Years

\begin{tabular}{|c|c|c|c|}
\hline & $C O A$ & $F D I$ & $C O$ \\
\hline Year 2006 & $0.010^{* *}$ & $0.010^{* *}$ & \\
\hline Year 2007 & $0.010^{* * *}$ & $0.010^{* * *}$ & \\
\hline Year 2008 & -0.004 & -0.004 & \\
\hline Year 2009 & $-0.049^{* * *}$ & $-0.049^{* * *}$ & \\
\hline Year 2010 & -0.006 & -0.006 & \\
\hline Year 2011 & -0.006 & -0.006 & \\
\hline Year 2012 & $-0.013^{* * *}$ & $-0.013^{* * *}$ & \\
\hline Year 2013 & $-0.012^{* *}$ & $-0.012^{* *}$ & \\
\hline Year 2006 × Treatment (2005-2008) & -0.007 & -0.007 & \\
\hline Year $2007 \times$ Treatment $(2005-2008)$ & $-0.008^{* *}$ & $-0.008^{* *}$ & \\
\hline Year 2008 × Treatment (2005-2008) & $-0.012^{* * *}$ & $-0.012^{* * *}$ & \\
\hline Year $2009 \times$ Treatment $(2005-2008)$ & $-0.017^{* * *}$ & $-0.017^{* * *}$ & \\
\hline Year $2010 \times$ Treatment (2005-2008) & $-0.015^{* * *}$ & $-0.015^{* * *}$ & \\
\hline Year 2011 × Treatment (2005-2008) & $-0.011^{* *}$ & $-0.011^{* *}$ & \\
\hline Year 2012 × Treatment (2005-2008) & $-0.014^{* * *}$ & $-0.014^{* * *}$ & \\
\hline Year 2013 × Treatment (2005-2008) & $-0.021^{* * *}$ & $-0.021^{* * *}$ & \\
\hline Constant & $0.050^{* * *}$ & $0.050^{* * *}$ & \\
\hline$R^{2}$ & 0.074 & 0.074 & \\
\hline
\end{tabular}

${ }^{*} p<.10,{ }^{* *} p<.05,{ }^{* * *} p<.01$.

Table A.9: Sector: Finance; Treatment (2005-2008): GDP \%

\begin{tabular}{|c|c|c|c|}
\hline & $C O A$ & FDI & $C O$ \\
\hline Year 2006 & $0.010^{* *}$ & $0.010^{* *}$ & \\
\hline Year 2007 & $0.010^{* * *}$ & $0.010^{* * *}$ & \\
\hline Year 2008 & -0.004 & -0.004 & \\
\hline Year 2009 & $-0.049^{* * *}$ & $-0.049^{* * *}$ & \\
\hline Year 2010 & -0.006 & -0.006 & \\
\hline Year 2011 & -0.006 & -0.006 & \\
\hline Year 2012 & $-0.013^{* * *}$ & $-0.013^{* * *}$ & \\
\hline Year 2013 & $-0.012^{* *}$ & $-0.012^{* *}$ & \\
\hline Year $2006 \times$ Treatment $(2005-2008)$ & -0.013 & -0.013 & \\
\hline Year 2007 × Treatment $(2005-2008)$ & $-0.015^{* *}$ & $-0.015^{* *}$ & \\
\hline Year 2008 × Treatment (2005-2008) & $-0.023^{* * *}$ & $-0.023^{* * *}$ & \\
\hline Year $2009 \times$ Treatment $(2005-2008)$ & $-0.033^{* * *}$ & $-0.033^{* * *}$ & \\
\hline Year $2010 \times$ Treatment $(2005-2008)$ & $-0.028^{* * *}$ & $-0.028^{* * *}$ & \\
\hline Year $2011 \times$ Treatment $(2005-2008)$ & $-0.020^{* *}$ & $-0.020^{* *}$ & \\
\hline Year 2012 × Treatment (2005-2008) & $-0.027^{* * *}$ & $-0.027^{* * *}$ & \\
\hline Year 2013 × Treatment $(2005-2008)$ & $-0.039^{* * *}$ & $-0.039^{* * *}$ & \\
\hline Constant & $0.050^{* * *}$ & $0.050^{* * *}$ & \\
\hline$R^{2}$ & 0.074 & 0.074 & \\
\hline
\end{tabular}

${ }^{*} p<.10,{ }^{* *} p<.05,{ }^{* * *} p<.01$. 
Table A.10: Sector: Metals; Treatment (2005-2008): Years

\begin{tabular}{|c|c|c|c|}
\hline & $C O A$ & $F D I$ & $C O$ \\
\hline Year 2006 & $0.010^{* *}$ & $0.010^{* *}$ & $0.010^{* *}$ \\
\hline Year 2007 & $0.010^{* * *}$ & $0.010^{* * *}$ & $0.010^{* * *}$ \\
\hline Year 2008 & -0.002 & -0.003 & -0.003 \\
\hline Year 2009 & $-0.051^{* * *}$ & $-0.051^{* * *}$ & $-0.050^{* * *}$ \\
\hline Year 2010 & $-0.009^{*}$ & $-0.009^{*}$ & -0.007 \\
\hline Year 2011 & -0.007 & -0.007 & -0.005 \\
\hline Year 2012 & $-0.015^{* * *}$ & $-0.015^{* * *}$ & $-0.013^{* * *}$ \\
\hline Year 2013 & $-0.011^{* *}$ & $-0.013^{* *}$ & $-0.010^{* *}$ \\
\hline Year $2006 \times$ Treatment $(2005-2008)$ & -0.001 & -0.001 & -0.001 \\
\hline Year $2007 \times$ Treatment $(2005-2008)$ & -0.001 & -0.001 & 0.002 \\
\hline Year 2008 × Treatment (2005-2008) & -0.008 & -0.008 & -0.009 \\
\hline Year $2009 \times$ Treatment $(2005-2008)$ & 0.008 & 0.012 & 0.001 \\
\hline Year $2010 \times$ Treatment $(2005-2008)$ & $0.016^{* *}$ & $0.019^{*}$ & 0.011 \\
\hline Year $2011 \times$ Treatment $(2005-2008)$ & 0.006 & 0.012 & $-0.008^{*}$ \\
\hline Year $2012 \times$ Treatment (2005-2008) & 0.011 & 0.016 & 0.001 \\
\hline Year $2013 \times$ Treatment $(2005-2008)$ & -0.006 & 0.004 & $-0.028^{* *}$ \\
\hline Constant & $0.050^{* * *}$ & $0.050^{* * *}$ & $0.050^{* * *}$ \\
\hline$R^{2}$ & 0.076 & 0.069 & 0.072 \\
\hline
\end{tabular}

${ }^{*} p<.10,{ }^{* *} p<.05,{ }^{* * *} p<.01$.

Table A.11: Sector: Metals; Treatment (2005-2008): GDP \%

\begin{tabular}{|c|c|c|c|}
\hline & $C O A$ & $F D I$ & $C O$ \\
\hline Year 2006 & $0.010^{* *}$ & $0.010^{* *}$ & $0.010^{* *}$ \\
\hline Year 2007 & $0.010^{* * *}$ & $0.010^{* * *}$ & $0.010^{* * *}$ \\
\hline Year 2008 & -0.005 & -0.005 & -0.004 \\
\hline Year 2009 & $-0.051^{* * *}$ & $-0.051^{* * *}$ & $-0.050^{* * *}$ \\
\hline Year 2010 & $-0.008^{*}$ & $-0.008^{*}$ & -0.007 \\
\hline Year 2011 & -0.007 & $-0.007^{*}$ & -0.005 \\
\hline Year 2012 & $-0.016^{* * *}$ & $-0.015^{* * *}$ & $-0.014^{* * *}$ \\
\hline Year 2013 & $-0.013^{* * *}$ & $-0.013^{* * *}$ & $-0.012^{* *}$ \\
\hline Year $2006 \times$ Treatment $(2005-2008)$ & -0.002 & -0.003 & 0.001 \\
\hline Year $2007 \times$ Treatment $(2005-2008)$ & 0.003 & 0.005 & $-0.022^{* * *}$ \\
\hline Year $2008 \times$ Treatment $(2005-2008)$ & $0.011^{* *}$ & $0.011^{* *}$ & $0.035^{* *}$ \\
\hline Year $2009 \times$ Treatment $(2005-2008)$ & 0.013 & $0.015^{*}$ & 0.004 \\
\hline Year $2010 \times$ Treatment $(2005-2008)$ & $0.018^{* * *}$ & $0.020^{* * *}$ & $0.038^{* * *}$ \\
\hline Year $2011 \times$ Treatment $(2005-2008)$ & $0.016^{*}$ & $0.021^{* *}$ & $-0.017^{* * *}$ \\
\hline Year $2012 \times$ Treatment (2005-2008) & $0.024^{* * *}$ & $0.025^{* * *}$ & $0.060^{* * *}$ \\
\hline Year $2013 \times$ Treatment $(2005-2008)$ & $0.010^{* *}$ & $0.013^{* *}$ & -0.007 \\
\hline Constant & $0.050^{* * *}$ & $0.050^{* * *}$ & $0.050^{* * *}$ \\
\hline$R^{2}$ & 0.054 & 0.051 & 0.077 \\
\hline
\end{tabular}

${ }^{*} p<.10,{ }^{* *} p<.05,{ }^{* * *} p<.01$. 
Table A.12: Sector: Real estate; Treatment (2005-2008): Years

\begin{tabular}{|c|c|c|c|}
\hline & $C O A$ & $F D I$ & $C O$ \\
\hline Year 2006 & $0.009^{* *}$ & $0.010^{* *}$ & $0.009^{* *}$ \\
\hline Year 2007 & $0.010^{* * *}$ & $0.010^{* * *}$ & $0.010^{* * *}$ \\
\hline Year 2008 & -0.002 & -0.004 & -0.003 \\
\hline Year 2009 & $-0.045^{* * *}$ & $-0.049^{* * *}$ & $-0.046^{* * *}$ \\
\hline Year 2010 & -0.003 & -0.006 & -0.003 \\
\hline Year 2011 & -0.002 & -0.006 & -0.002 \\
\hline Year 2012 & $-0.010^{* *}$ & $-0.013^{* * *}$ & $-0.010^{* *}$ \\
\hline Year 2013 & $-0.008^{*}$ & $-0.012^{* *}$ & $-0.009^{*}$ \\
\hline Year $2006 \times$ Treatment $(2005-2008)$ & 0.011 & 0.007 & 0.011 \\
\hline Year $2007 \times$ Treatment $(2005-2008)$ & 0.004 & $0.010^{* * *}$ & 0.003 \\
\hline Year 2008 × Treatment (2005-2008) & -0.016 & -0.007 & -0.017 \\
\hline Year $2009 \times$ Treatment $(2005-2008)$ & $-0.061^{* * *}$ & $-0.095^{* * *}$ & $-0.055^{* *}$ \\
\hline Year $2010 \times$ Treatment $(2005-2008)$ & -0.038 & $-0.012^{* *}$ & -0.041 \\
\hline Year $2011 \times$ Treatment $(2005-2008)$ & -0.044 & $-0.015^{* * *}$ & -0.047 \\
\hline Year $2012 \times$ Treatment (2005-2008) & $-0.043^{*}$ & $-0.015^{* * *}$ & $-0.047^{*}$ \\
\hline Year 2013 × Treatment (2005-2008) & $-0.051^{* *}$ & $-0.037^{* * *}$ & $-0.052^{* *}$ \\
\hline Constant & $0.050^{* * *}$ & $0.050^{* * *}$ & $0.050^{* * *}$ \\
\hline$R^{2}$ & 0.022 & 0.060 & 0.023 \\
\hline
\end{tabular}

${ }^{*} p<.10,{ }^{* *} p<.05,{ }^{* * *} p<.01$.

Table A.13: Sector: Real estate; Treatment (2005-2008): GDP \%

\begin{tabular}{llll}
\hline & $C O A$ & $F D I$ & $C O$ \\
\hline Year 2006 & $0.009^{* *}$ & $0.010^{* *}$ & $0.009^{* *}$ \\
Year 2007 & $0.010^{* * *}$ & $0.010^{* * *}$ & $0.010^{* * *}$ \\
Year 2008 & -0.001 & -0.004 & -0.002 \\
Year 2009 & $-0.047^{* * *}$ & $-0.049^{* * *}$ & $-0.047^{* * *}$ \\
Year 2010 & -0.003 & -0.006 & -0.003 \\
Year 2011 & -0.002 & -0.006 & -0.002 \\
Year 2012 & $-0.010^{* *}$ & $-0.013^{* * *}$ & $-0.010^{* *}$ \\
Year 2013 & $-0.009^{*}$ & $-0.012^{* *}$ & $-0.009^{* *}$ \\
Year 2006 $\times$ Treatment $(2005-2008)$ & 0.022 & 0.181 & 0.022 \\
Year 2007 $\times$ Treatment $(2005-2008)$ & -0.007 & $0.266^{* * *}$ & -0.008 \\
Year 2008 $\times$ Treatment $(2005-2008)$ & $-0.108^{* *}$ & -0.186 & $-0.107^{* *}$ \\
Year 2009 $\times$ Treatment $(2005-2008)$ & $-0.143^{* * *}$ & $-2.495^{* * *}$ & $-0.139^{* * *}$ \\
Year 2010 $\times$ Treatment $(2005-2008)$ & $-0.137^{*}$ & $-0.313^{* *}$ & $-0.136^{*}$ \\
Year 2011 $\times$ Treatment $(2005-2008)$ & -0.165 & $-0.384^{* * *}$ & -0.165 \\
Year 2012 $\times$ Treatment $(2005-2008)$ & $-0.158^{*}$ & $-0.395^{* * *}$ & $-0.158^{*}$ \\
Year 2013 $\times$ Treatment $(2005-2008)$ & $-0.169^{* * *}$ & $-0.970^{* * *}$ & $-0.168^{* * *}$ \\
Constant & $0.050^{* * *}$ & $0.050^{* * *}$ & $0.050^{* * *}$ \\
\hline$R^{2}$ & 0.024 & 0.060 & 0.024 \\
\hline$* p<.10{ }^{* *} p<.05,{ }^{* * *} p<.01$. & & &
\end{tabular}


Table A.14: Sector: Transport; Treatment (2005-2008): Years

\begin{tabular}{|c|c|c|c|}
\hline & $C O A$ & $F D I$ & $C O$ \\
\hline Year 2006 & $0.010^{* *}$ & $0.010^{* *}$ & $0.010^{* *}$ \\
\hline Year 2007 & $0.010^{* * *}$ & $0.010^{* * *}$ & $0.011^{* * *}$ \\
\hline Year 2008 & -0.003 & -0.004 & -0.002 \\
\hline Year 2009 & $-0.052^{* * *}$ & $-0.050^{* * *}$ & $-0.052^{* * *}$ \\
\hline Year 2010 & -0.007 & -0.006 & -0.007 \\
\hline Year 2011 & -0.005 & -0.005 & -0.006 \\
\hline Year 2012 & $-0.013^{* * *}$ & $-0.013^{* * *}$ & $-0.013^{* *}$ \\
\hline Year 2013 & $-0.011^{* *}$ & $-0.012^{* *}$ & $-0.011^{* *}$ \\
\hline Year 2006 × Treatment (2005-2008) & -0.004 & $0.013^{* * *}$ & -0.006 \\
\hline Year $2007 \times$ Treatment $(2005-2008)$ & -0.003 & $0.015^{* * *}$ & -0.005 \\
\hline Year 2008 × Treatment (2005-2008) & -0.007 & $0.029^{* * *}$ & -0.011 \\
\hline Year $2009 \times$ Treatment $(2005-2008)$ & $0.023^{* *}$ & $0.052^{* * *}$ & $0.024^{*}$ \\
\hline Year $2010 \times$ Treatment $(2005-2008)$ & 0.010 & $0.013^{* * *}$ & 0.011 \\
\hline Year $2011 \times$ Treatment $(2005-2008)$ & -0.002 & $-0.021^{* * *}$ & -0.001 \\
\hline Year $2012 \times$ Treatment (2005-2008) & -0.002 & $-0.009^{*}$ & -0.001 \\
\hline Year 2013 × Treatment (2005-2008) & -0.007 & $-0.011^{* *}$ & -0.007 \\
\hline Constant & $0.050^{* * *}$ & $0.050^{* * *}$ & $0.050^{* * *}$ \\
\hline$R^{2}$ & 0.058 & 0.073 & 0.057 \\
\hline
\end{tabular}

${ }^{*} p<.10,{ }^{* *} p<.05,{ }^{* * *} p<.01$.

Table A.15: Sector: Transport; Treatment (2005-2008): GDP \%

\begin{tabular}{|c|c|c|c|}
\hline & $C O A$ & $F D I$ & $C O$ \\
\hline Year 2006 & $0.011^{* *}$ & $0.010^{* *}$ & $0.011^{* *}$ \\
\hline Year 2007 & $0.011^{* * *}$ & $0.010^{* * *}$ & $0.011^{* * *}$ \\
\hline Year 2008 & -0.003 & -0.004 & -0.003 \\
\hline Year 2009 & $-0.050^{* * *}$ & $-0.050^{* * *}$ & $-0.050^{* * *}$ \\
\hline Year 2010 & -0.006 & -0.006 & -0.006 \\
\hline Year 2011 & -0.005 & -0.005 & -0.005 \\
\hline Year 2012 & $-0.013^{* * *}$ & $-0.013^{* * *}$ & $-0.013^{* * *}$ \\
\hline Year 2013 & $-0.012^{* *}$ & $-0.012^{* *}$ & $-0.012^{* *}$ \\
\hline Year $2006 \times$ Treatment (2005-2008) & $-0.015^{* * *}$ & $0.340^{* * *}$ & $-0.015^{* * *}$ \\
\hline Year $2007 \times$ Treatment $(2005-2008)$ & $-0.009^{* * *}$ & $0.392^{* * *}$ & $-0.009^{* * *}$ \\
\hline Year $2008 \times$ Treatment (2005-2008) & $-0.011^{* * *}$ & $0.778^{* * *}$ & $-0.011^{* * *}$ \\
\hline Year $2009 \times$ Treatment $(2005-2008)$ & 0.009 & $1.385^{* * *}$ & 0.009 \\
\hline Year $2010 \times$ Treatment $(2005-2008)$ & 0.001 & $0.334^{* * *}$ & 0.001 \\
\hline Year $2011 \times$ Treatment $(2005-2008)$ & -0.005 & $-0.553^{* * *}$ & -0.005 \\
\hline Year $2012 \times$ Treatment $(2005-2008)$ & -0.001 & $-0.232^{*}$ & -0.001 \\
\hline Year $2013 \times$ Treatment $(2005-2008)$ & -0.003 & $-0.286^{* *}$ & -0.003 \\
\hline Constant & $0.050^{* * *}$ & $0.050^{* * *}$ & $0.050^{* * *}$ \\
\hline$R^{2}$ & 0.075 & 0.073 & 0.075 \\
\hline
\end{tabular}

${ }^{*} p<.10,{ }^{* *} p<.05,{ }^{* * *} p<.01$. 